\title{
Measuring the Development of Knowledge-Based Economy in Taiwan*
}

\author{
CHIA-YeN YANG AND HSIU-YING LIN
}

Assaciate Research Fetlow, and Assistant Research Fellow; Taiwan Institute of Economic Research

\begin{abstract}
The progress of information and communication technology (IC1) has been reyarded as one cruial factor bringing about the phenomenon of knowledge-based econom, while other faitors subb aw buman resource development, and rekated institutional settings bave also played important roles bebind the scene. Our measurement reflects Taiwan's patential knouledge-based economy (KBE) development, which nevertheless indicates considerable mom for inpmement. Except for ICI investment, the other knowledge imestment indicators supported the perspective of 'Iaiwan's KBE development. However, the knowledge diffusion is perbaps the ueakest part of Taiwan's KBE development: Taiwan needs much improwement in order to stay clase to the developed countries. Finally, as for the knowledge output and application. Taiwan's nutstanding performance in research publication and patents is consistent with that in research and development (RED) of buman resoures, but the obviously urak performance of knouledge-intensive service sector might bate resulted from Taiwar's relative disatvantages indicated by the measurement of the knowledge diffusion. Given the above status of Taiwan's KBE development, Taiwan will inevitably encounter the following two major challenges: one is related to the difficulty in upgrading Taiwan's science and technology (SET), and the otber is related to the noted isstues of digital divide and economic stability.
\end{abstract}

\footnotetext{
An earlier version of this paper presented at the International Conference on Measuring and Evaluating Industrial RKD and Innovation in the Knowledge-Based Economy at Taipei on Auguss 23-24, 2001. The tesearch was funded by the Department of Industrial Technology, Ministry of Economic Affaits, R.O.C. Direct all correspondence to Chia-Yon Yang, associate research fellow at the Taiwan Instutute of Economic Research, $7^{\text {th }}$ Hloor, 16.8 Tehui Street, Taipei, Tawan; Phone: 886-2.2586-5000 ext.227; Frx: 8862.2586-3245; E-matil: d32119(0)ties.otg.tw, and Hsiu-Ying Lin, assistant tesearch tellow ac the Faiwan Institute of Fconomic Rescarch, 7th, floot, 16-8 Tchui Strect, Taipei, Tawwan; Phone: 886-2-2586-5000 ext.221; Fax: 886-2-2586-3245; E-mail: d7465(ätier.org.tw.
} 


\section{INTRODUCTION}

$\mathrm{F}$

or the cra of knowledge-based economy (KBE), Organization for Fconomic Cooperation and Development (OECD) inembers. while strengthening their policies for promoting science and echnology ( $\mathrm{S} \& \mathrm{l}^{\circ}$ ) research and development (R\&D) and innovation, have also been working on establishing a beter indicator system for national innovation capability so that policy-makets could reccive timcly information and make policy adjustment accordingly. As a part on the world competition, Taiwan needs to advance along with the orhers for hetter survival. Motivated as such, this paper aims at (1) providing a measurement framework with several widely used indicators, and (2) presenting and interpreting the measurement results. It is our hope that our measurement would provide some unctul information for our government. as well as researchets su that better policies for the related ficld could be made in Taiwan.

This paper is organized as follows: first, the concept and the emergence of the $\mathrm{KBE}$ : will be briefly discussed, and then an indicator system will be proposed and the measurement result of the development of KBE in Taiwan will be presented, followed by our interpretation and conclusion.

\section{KBE AND ITS EMERGENCE}

About ten years ago the world wirnessed the economic prosperity in Japan and some South East Asian countries, which were believed as rising stars in the near future. However, the Japanese economy has since suffered and the South East Asian countries were hard hit by financial crises. Their perspectives seem no longer bright. In contrast, the economy of the United States has experienced ten-year long prospcrity, with the record-breaking continual coonomic growth. and low unemployment and inflation rates.

The surprising performance of the L.S. economy has caught the workd's attention, and mumerous researches were done for the possible reasons and answers for such long-lasting presperity. In 1926 OECD published an article encirled, "Tlue Knowledge-Based Econonyy," defined as "economies which are ditectly based on the production, distriburion and use of knowledge and intormation." Subsequene researches by kuropean Community (EC) (2000) and Asia-Pacific Economic Cooperation (APEC) (2000) refined the concept of $\mathrm{KBE}$ as "knowledge-driven economy (KDE)," and argued that the impact of knowledge creacion, diftusion, and its use does not reach only a few "hi-cech" industries, but all economic sectors.

The KBE can be characterized statically by the large output proportion of so-called "knowledge-intensive inclustries" in GIDP, and dynamically by the specding of innovations. Knowledge-intensive industries mean high intensity of knowledge as a lactor 
of production and transaction. OECD used such criteria as expenditure on personncl education and training, $R \& D$, and software for identifying knowledge-intensive industries. The efforts lead to the following: (1) knowledge-intensive manufacturing industries include high-technology industries such as manufacturing of aircraft, office and computing equipment, drugs and medicines, radio, TV and communication equipment, and medium-high-technology industries, such as manufacturing of motor vehicles, professional goods, electrical machinery, chemicals and so on; (2) knowledge-intensive service industries include financial industries, insurance industries, telecommunication services, asset-evaluation services, business services, and social and personal services.

The phenomena of $\mathrm{KBE}$ are usually attributed to the non-rivalrous nature of knowledge; i.e., the use of knowledge in principle is not limited by location and time, in contrast to most of the other factors of production. Moreover, the non-rivalrous benefit of knowledge has been tremendously enhanced by the information and communication rechnology (ICT), since the knowledge diffusion has become much easier and less expensive, facilitating $R \& D$ and innovation activities, resulting in faster accumulation of human knowledge stock.

It is our argument, therefore, that ICT as an enabling technology for KBE rests on three reasons: (1) ICT applied in production raises the net value of production (direct productivity up and cost down); (2) ICT reduces the transaction costs, resulting in a higher degree of specialization and labor division, which additionally enhance productivity; (3) faster innovation activities and knowledge accumulation also help greatly the progress of technology, making feasible the continual rise in productivity. The almost simultaneous emergence of prosperous Internet and the U.S. economy might serve as one picce of the supporting evidence.

However, the development of ICT does not come from nowhere. The progress and wide-spread use of ICT are tremendous time-consuming process for human resource development (HRD), both in quality and quantity. On the other hand, institutional cstablishment for promoting intellectual property, $\mathrm{R} \& \mathrm{D}$, and innovations also serves as the prerequisite for technology progress in a society, since personal spontaneous incerests in $\mathrm{R} \& \mathrm{D}$ and innovation cannot be a reliable driving force. In other words, the emergence of $\mathrm{KBE}$ could nor be fostered without the support of HRD and related institutions.

Finally, the emergence of $\mathrm{KBE}$ can also be attributed to the promotion and advancement of free international trade. From General Agreement on Tariffs and Trade (GA'T) to World Trade Organization (WTO), more and more countrics have taken part in international trade, and the subscyuent participation of developing economies such as Sourh East Asia, China, East Europe, and India, have resulted in excess supply of the low skill labor and labor-intensive products. The fact has led to the situation where the key competitive advantage in the global market does nor rest solely on the inexpensive labor and other physical resources, which are now largely available to all countries, but also relies increasingly on the technological strength. 


\section{THE MEASI JREMENT FOR THE DEVELOPMENT OF TAIWAN'S KBE}

\section{Description of the Proposed Indicator System}

The system of KBE indicators proposed in this paper is formed according to the following criteria of indicator selection:

(1) Commonness. The indicators selected into our system will be anong those widely used by many countries in the world. The more comprehensive studies in the KBE mcasurement include OECD (1999), APEC (2000), U.K. (1999), and Australia (2000), which provide important references for the indicator system proposed in this paper.

(2) Comparability. A thorough measurement has to include self-evaluation as well as international comparison so that the relative ranking and status of competitiveness among nations in the world can be explicitly shown. Indicators also require the same definition as the comparison basis.

(3) Data availability. Besides the same definitions of indicators, data availability constitutes an impottant factor or constraint for international comparison.

Table 1.l. Slmmaky of THE Proposed l.NDiCATOR System

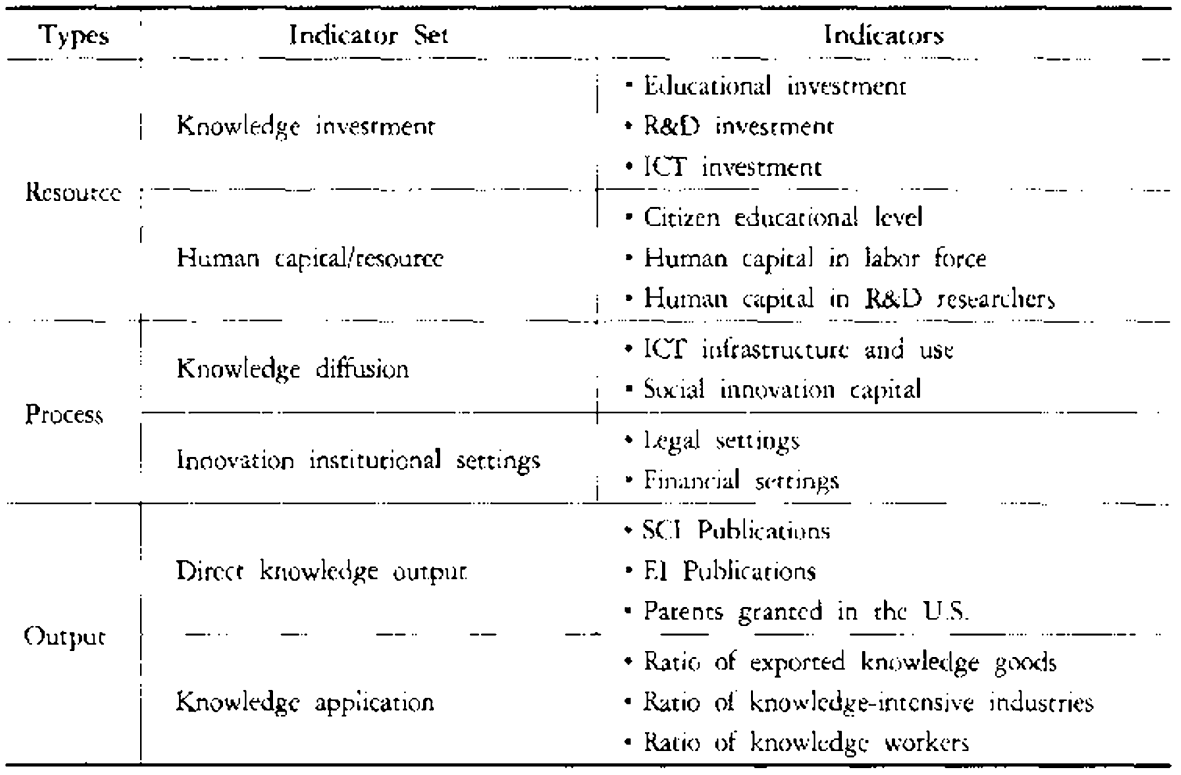

The indicator system proposed in this paper consists of three sets: resource indicators, process indicators, and result indicators. The set of resource indicators serves as the 
proxies of measuring knowledge input level, including mainly knowledge investments (e.g., educational investment, $\mathrm{R} R \mathrm{D}$ investment, and ICT investment) and human capital or resources. Secondly, the set of process indicators serves as the proxies of measuring knowledge diffusion level, including ICT infrastructure and use, social innovation capital, and several institutional factors. Finally, the set of result indicators serves as the proxies of measuring knowledge output and application, including the number of Science Citation Index (SCI) and Engineering Index (EI) publications, the number of patents granted in the U.S., the ratio of exported knowledge-intensive product to GDP, the ratio of knowledge-intensive industries to all industries, the employment tatio of knowledge workers, and so on. The indicator system is summarized in Table 1.1.

\section{The Result of Measurement}

\section{(1) Knowledge Investment}

It is difficult to measure knowledge investment, not only because of the absence of clear definition of the term, knowledge investment, but also because of data differentiation. The most common definition for knowledge investment is from OECD (1999), which involves $R \& D$ expenditure, educational expenditure, and software investment as the major indicators. The indicators for knowledge investment are summarized in Table 2.1 .

TABLE 2.1. SUMMARY OF KNOWLEUGE INVESTMEN I INDICATORS

\begin{tabular}{|c|c|c|}
\hline Type & Indicators & Reference \\
\hline $\begin{array}{l}\text { Educational } \\
\text { Investment }\end{array}$ & $\begin{array}{l}\text { - Public education spending/GDP } \\
\text { - National cducation spending/GDP }\end{array}$ & $\begin{array}{l}\text { - OECD, "Education at Glance" } \\
\text { - UNESCO } \\
\text { - Ministry of Education, RO.C. } \\
\text { httpi/aww.cdu.tw/resourceis-1.hem }\end{array}$ \\
\hline $\begin{array}{l}\mathrm{R} \quad \& \quad \mathrm{D} \\
\text { Investment }\end{array}$ & $\begin{array}{l}\text { - Gross Expenditure of R\&D (GERD) } \\
\text { - GERD/GDP } \\
\text { - GERD composition }\end{array}$ & $\begin{array}{l}\text { - OECD, ANBERD database } \\
\text { - OECD, MSTl database } \\
\text { - OECD, "STI scorcboard 1999" } \\
\text { - Indicators of S\&T, RO.C. }\end{array}$ \\
\hline $\begin{array}{l}\text { I } \quad \text { C } ~ \\
\text { Investment }\end{array}$ & $\begin{array}{l}\text { - ICT spending/GDP } \\
\text { - Software spending/GDP }\end{array}$ & WITSA \& IDC "Digital Planet 2000" \\
\hline
\end{tabular}

Note: ANBERB Analytical Business Enterprise Research and Development; MSTI Main Science and Technology Indicator; STI Scicuee and Technolugy Indicator; WITSA World Information Techonology and Service Association; IDC Incernational Data Corporation.

\section{a. Educational Investment}

In theory educational expenditure includes that of formal education and on-the-job training, but owing to data availability, in this paper only public expenditure in 
education is used as the sole indicator for international comparison.

As shown in Table 2.2, the ratio of public expenditure in education to all government spending in Taiwan in 1998 reached its peak of $15.7 \%$. On the other hand, public expenditure in education as the proportion of GDP reached its peak of $6.23 \%$ in 1992 up from $4.63 \%$ in 1988.

\section{Tabie 2.2. Pumlic Fodicational fixpenditerf in taiwan}

¿Unj:: NTS millicii, e;

\begin{tabular}{|c|c|c|c|c|c|c|}
\hline & & Nom:ina! & Real & Edu Spendingi & Edu Spending & Edu, S\&T Spending; \\
\hline Year & Amount & Girowth Rate & Growth Rate & Gis. Spending & GDP & (ios: Spending \\
\hline 1988 & $: 630194$ & . & - & $1 / 30$ & 46.5 & $1.3 .61)$ \\
\hline 1989 & 202364 & 2108 & 20.12 & 17.47 & 5.14 & $15.1 \%$ \\
\hline 1990 & $217-488$ & 2230 & 17.88 & 17.77 & 5.55 & 14.93 \\
\hline$\lfloor \%$ & 290020 & 17.19 & 1281 & 17.86 & 6.03 & 15.31 \\
\hline 1992 & 332463 & 14.63 & 11.02 & 18.43 & 6.23 & 15.13 \\
\hline 1993 & 350053 & 5.29 & 1.64 & 18.58 & 5.91 & 15.24 \\
\hline 1994 & $36(1) 02$ & 481 & 2.80 & 19.36 & 5.68 & 15.40 \\
\hline 1905 & 407596 & 11.09 & 8.89 & 19.50 & 5.81 & 15.02 \\
\hline 1996 & 420905 & 3.27 & 0.15 & 18.91 & 5.48 & 1506 \\
\hline 1997 & 430676 & 2.32 & 0.63 & 18.54 & 5.79 & 15.27 \\
\hline 1998 & 453090 & 5.20 & 2.50 & 18.80 & 5,07 & $15 \div 0$ \\
\hline
\end{tabular}

Nate: Lidi: education; Gov. government.

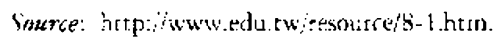

Tabie 2.3. International. Comparison of Prblic: Expenditure on foughtion AS PERCFNTAGE OF GDP

(Linit:

\begin{tabular}{|c|c|c|c|c|c|c|c|c|c|c|c|c|c|c|}
\hline Narion & 1985 & 1986 & 1987 & 1988 & 1989 & 1990 & 1901 & 1992 & 3993 & 1994 & 1995 & 1996 & 1997 & ;i) \\
\hline U.S. & 4.9 & 6.8 & 5 & $5 . !$ & 5.2 & 5.2 & - & 5.4 & 5.3 & 5.1 & - & - & - & - \\
\hline Canata & 6.5 & 6.8 & 6.7 & 6.6 & 6.4 & 6.8 & 7.3 & $? .5$ & 1.2 & 6.9 & - & - & ـ & - \\
\hline Germany & & & & & & & & & 4.8 & 4.7. & 4.8 & 1.8 & & - \\
\hline L.K. & 4.9 & ५.9 & 1.8 & $i=$ & 4.7 & 4.9 & 5.2 & 5.4 & 5.5 & 5.4 & 5.3 & - & & \\
\hline 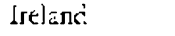 & 6.4 & 6.5 & 6.7 & 6.1 & 5.8 & 5.6 & $5 . ?$ & 6 & 6.2 & 6.3 & 6 & 6 & . & - \\
\hline Italy & 5 & $?$ & +9 & 4. 1 & 3.2 & 3.1 & 4.2 & 5.2 & 4.9 & 4.7 & 4.9 & . & 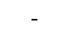 & - \\
\hline Sweder. & 7.7 & 7.5 & 7.3 & $6 . \overline{7}$ & 7.3 & 7.7 & 8 & 8.1 & 8 & 8.1 & 8.3 & - & - & - \\
\hline Denmask & i & 6.8 & 7.2 & 1.4 & 7.2 & 9.1 & 8.1 & $? .8$ & $\therefore i$ & 8.1 & 6.9 & & & - \\
\hline Netherlands & 6.4 & 6.5 & 6.9 & 6.5 & 6 & 6 & 5.9 & 5.4 & 5.2 & 5.2 & 5.1 & - & - & \\
\hline Austsaliz & 5.6 & 5.1 & 5.1 & 4.9 & 5.1 & 5.3 & 5.5 & 5.9 & 5.6 & 5.4 & 5.5 & - & & \\
\hline New Zexaland & 4.7 & 5 & 5.4 & 5.8 & 79 & 6.5 & 7.4 & $\because .4$ & 7 & 6.8 & 7.5 & 7.3 & - & - \\
\hline Japin & j & 49 & 4.8 & 4.6 & 4.7 & 4.1 & 4.7 & 4.7 & 48 & 4.8 & 4.8 & - & - & - \\
\hline Taiwan & 4.1 & 4.2 & 3.8 & a & 4.3 & 4.8 & 5.3 & 5.6 & 5.8 & 5.6 & 5.5 & 5.6 & 5.4 & 5.1 \\
\hline Singalyore & 4.4 & 4.1 & 3.9 & 3.3 & 3 & 3 & $3 . !$ & 3.2 & 3.1 & 3 & 3 & - & - & - \\
\hline South Korea & 4.5 & 4.1 & 38 & 3.1 & 3.5 & 3.5 & 4 & 4.2 & 6.4 & 3.7 & 3.7 & - & - & - \\
\hline
\end{tabular}

SUurce: LNESCO. 1998. 
Compared with other countries, as shown in Table 2.3, in 1995 Denmark's public expenditure in educarion as the proportion of GDP was $6.9 \%$ leading all other countries, followed by France, Netherlands, Canada, and other North European countries. The ratio of Taiwan in 1995 was $5.81 \%$, higher than the averages of EU $(5.1 \%)$ and OECD (4.6\%). It revealed that Taiwan's public expenditure in education was no less that the average of the developed countries, but the ratio had been decreasing in recent years.

\section{b. $R \& D$ Investment}

Owing to the absence of data for the spending on innovations in Taiwan, only R\&D-related data is used for self-evaluation and international comparison. As shown in Table 2.4, in 1999 national $R \& D$ expenditure as the proportion of GDP was $2.05 \%$, higher than that $(1.98 \%)$ in 1998 , showing a rise. When examining the sources of R\&D investment, privare business sector was the main contributor, constituting $62.9 \%$ of the total $\mathrm{R} \& \mathrm{D}$ expenditure. Mcanwhile, $\mathrm{R} \& \mathrm{D}$ spending by universities and nonprofit research institutes showed obvious growth, about eight times from 1997 to 1999 , while R\&D spending by government decreased over the same petiod, as shown in Table 2.5 .

TAHEE 2.4. R\&D EXPENDITURE IN TAIWAN

\begin{tabular}{|c|c|c|c|c|c|c|c|c|c|}
\hline \multirow{3}{*}{ Year } & \multicolumn{6}{|c|}{ R\&D Spending } & \multicolumn{3}{|c|}{ R\&D Spending/GDP } \\
\hline & \multicolumn{2}{|c|}{ National } & \multicolumn{2}{|c|}{ Business } & \multicolumn{2}{|c|}{ Manufacturing } & \multirow{2}{*}{\begin{tabular}{|c} 
National \\
$\%$
\end{tabular}} & \multirow{2}{*}{$\frac{\text { Busines }}{\%}$} & \multirow{2}{*}{$\begin{array}{c}\begin{array}{c}\text { Manu- } \\
\text { facturing }\end{array} \\
\frac{\%}{\%}\end{array}$} \\
\hline & Amount & Growth & Amount & Growth & Amount & Growth & & & \\
\hline 1988 & 43,830 & 18.10 & 20,948 & -4.63 & 20,826 & 3.85 & 1.24 & 0.59 & 0.59 \\
\hline 1989 & 54,784 & 20.99 & 30,695 & 41.86 & 30,510 & 41.83 & 1.39 & 0.78 & 0.77 \\
\hline 1990 & 71,548 & 25.87 & 42,240 & 32.64 & 38,933 & 23.00 & 1.66 & 0.98 & 0.90 \\
\hline 1991 & 81,765 & 10.04 & 43,836 & -0.07 & 40,602 & 0.42 & 1.70 & 0.91 & 0.84 \\
\hline 1992 & 94,828 & 12,32 & (4),825 & 10.08 & 46,512 & 10.9 .4 & 1.78 & 0.93 & 0.87 \\
\hline 1993 & 103,617 & 5.48 & 58,968 & 14.25 & 56,750 & 17.78 & 1.75 & 1.00 & 0.96 \\
\hline 1994 & 114,682 & 8.55 & $65,921$. & 9.64 & 63.552 & 9.83 & 1.77 & 1.02 & 0.98 \\
\hline 1995 & 125,031 & 6.87 & 71,972 & 7.02 & 70,162 & 8.22 & 1.78 & 1.03 & 1.00 \\
\hline 1996 & 137,955 & 7.00 & 79.806 & 7.54 & $77,7(36$ & 7.41 & 1.80 & 1.04 & 1.01 \\
\hline 1997 & 156,321 & 11.41 & 95,968 & 18.26 & 93,786 & 18.70 & 1.88 & 1.15 & 1.13 \\
\hline 1998 & 176,455 & 10.35 & 111,422 & 13.12 & 108,331 & 12.54 & 1.98 & 1.25 & 1.21 \\
\hline 1999 & 190,520 & 9.51 & 120,597 & 9.79 & 117307 & 9.85 & 2.05 & 1.28 & 1.25 \\
\hline
\end{tabular}

Source: NiSC, (2000), Indicators of S\&T ROX:

In Table 2.6, it is observed that in 1999 the U.S. ranked the first in R\&D spending, followed by Japan, Germany, France, U.K., South Korea, Iraly, Canada, China, Netherlands, Sweden, Australia, Spain, and Taiwan. While Taiwan ranked 14 ${ }^{\text {th }}$, the 
gap between the L.S. and Tawan has grown, and China had exceeded Taiwan in total $\mathrm{R} \& \mathrm{D}$ expenditure since 1996 , ranking $9^{\text {th) }}$ in 1999. As for the ratio of $\mathrm{R} \times \mathrm{D}$ to GDP, Sweden ranked the first at 3.7\% in 1997, followed by Finland's $3.09 \%$ (in 1999), Japan's 3.04\% (in 1998), Swiss's 2.73\% (in 1996), the U.S''s 2.65\%, and South Korea's 2.55\% (in 1998), while Germany, France, and Taiwan were all just above $2 \%$, and Denmark and Netherlands close to $2 \%$. As for the sources of $R \& D$ investment, the average $R \& D$ spending by privace business sector of OECD countries was also around $60 \%$, with Japar's $72.6 \%$ ranking the first.

Table 2.5. Compositjon of R\&D Expenditure in T'alwan

(Liur: NTS million,

\begin{tabular}{|c|c|c|c|c|c|c|c|}
\hline \multirow{2}{*}{$\begin{array}{l}\text { Spending Sectors } \\
\text { Source Sextors }\end{array}$} & & \multicolumn{2}{|c|}{ Business } & \multirow{2}{*}{$\frac{\text { Research }}{1998}$} & \multirow{2}{*}{$\begin{array}{c}\text { Institute } \\
1999 \\
\end{array}$} & \multicolumn{2}{|c|}{ Injersities } \\
\hline & & 1958 & 1999 & & & 1998 & 1999 \\
\hline \multirow{4}{*}{ Total } & Amount & $1] 1,422$ & 120,597 & $44,3 \div 1$ & 17,720 & 21.291 & 22,204 \\
\hline & Nominal Growth Rate & 16.10 & 8.73 & 5.51 & 7.62 & 16.17 & 4.29 \\
\hline & Real Growth Rase & 13.12 & 9.78 & 2.80 & 9.16 & 13.18 & 5.78 \\
\hline & Proportion & 100 & 100 & 100 & 100 & 100 & 100 \\
\hline \multirow{4}{*}{ Grovernment } & Amount & 10.542 & 10,728 & 38,308 & 41,720 & 20,533 & 19,679 \\
\hline & Nominal Growth Rare & 8.28 & 1.76 & 4.96 & 8.91 & 17.19 & -4.16 \\
\hline & Rual Growth Rate & 5.50 & 3.22 & 2,26 & 10.46 & 14.18 & $-2,74$ \\
\hline & Proportion & 9.50 & 8.90 & 86.40 & 87.10 & 26.40 & 88.60 \\
\hline \multirow{4}{*}{ Private } & Amount & $(00,880)$ & 109,869 & 6,023 & 5,999 & 758 & 2,525 \\
\hline & Nominal Groswth Rate & 7.90 & 8.91 & 9.16 & -0.56 & -6.07 & 233.11 \\
\hline & Real Growth Rate & 5.13 & $10 .\{7$ & 6.35 & 0.86 & -8.48 & 2378 \\
\hline & Proportion & 90.50 & 91.10 & 13.603 & 12.60 & 3.60 & 11.40 \\
\hline
\end{tabular}

Sulare: TlER

\section{c. ICI Investment}

According to a study entitled, "Digital Plant The Global Information Fconomy" by WITSA and IDC, ICT expenditure consists of three parts: (1) spending on IT hardware, (2) spending on I'T service and software, and (3) spending on telecommunication. In their 2000 report, 55 countries were investigated for ICT expenditure, and as shown in Table 2.7 , the first five countries in ranking order were the L.S., Japan, Germany, U.K., and France. In 1999, the BCT spending of the U.S. were US $\$ 761.9$ billion, abour twice as large as that of Japan's LS\$ 362 billion and more that the total of the other fout countric's spending. The total IC.T spending of the first five accounted for $68.9 \%$ of the world's IC.T spending, while the share of the U.S. was $35.4 \%$ and Japan $16.8 \%$.

The ICT spending in US\$ of countries in the Asia Pacific area in 1999 is as follows: Japan 362 billion, China 47.9 billion, Australia 36.8 billion, South Korea 22.4 billion. Taiwan 16 billion, India 15.5 billion, Hong Kong 12.8 billion, and Singapore 8 billion. Considering the ratio of ICI spending to GDP, the world average in 1999 
was $6.6 \%$, rising from $5.6 \%$ in 1992 . The ratios of different countries ranged from $3 \%$ to $9 \%$. Generally speaking, higher ratios are observed in the English-speaking and North European countries, with New Zealand's $10.5 \%$ ranking the fitst. In Asia, the ranking is as follows: Hong Kong $8.3 \%$, Singapore $7.7 \%$, Vietnam 7.4\%, Japan $7.1 \%$, China $4.9 \%$, while Tawan's $4.8 \%$ and South Korea's $4.4 \%$ seemed relatively small.

TABle 2.6. INTERNATIONAL COMPARISON OF R\&D EXPENDITLIRE IN 1999

\begin{tabular}{|c|c|c|c|c|c|}
\hline & \multicolumn{5}{|c|}{ National R\&D National R\&D Business $R \& D$ Business $R \& D$ Business $R \& D$} \\
\hline & $\begin{array}{l}\text { US\$ million } \\
\text { (current PPP) }\end{array}$ & $\begin{array}{c}\text { Share in GDP } \\
\&\end{array}$ & $\begin{array}{l}\text { US } \$ \text { million } \\
\text { (current PPP) }\end{array}$ & $\begin{array}{c}\text { Share in GDP } \\
\&\end{array}$ & $\begin{array}{c}\text { Share in DPI } \\
\&\end{array}$ \\
\hline US.S. & 243,548 & 2.65 & 184,379 & 2.01 & 2.36 \\
\hline Japan $^{\prime}$ & 92,663 & 3.04 & 65,974 & 2.17 & 2.44 \\
\hline Germany & 46,218 & 2.38 & 31,721 & 1.63 & 2.10 \\
\hline France: & 27,880 & 2.18 & 17,289 & 1.35 & 1.83 \\
\hline U.K.' & 23,445 & 1.83 & 15,423 & 1.20 & 1.64 \\
\hline South Korea' & 16,981 & 2.55 & 11,941 & 1.79 & 2.17 \\
\hline Italy & 13,311 & 1.02 & 7,158 & 0.56 & 0.73 \\
\hline Canarla & 12,775 & 1.62 & 8,042 & 1.00 & 1.26 \\
\hline China ${ }^{4}$ & 8,200 & 0.83 & 3,019 & 0.31 & - \\
\hline Netherlands' & 7,392 & 1.95 & 4,004 & 1.06 & 1.36 \\
\hline Sweden ${ }^{2}$ & 6,845 & 3.7 & 5,124 & 2.77 & 4.40 \\
\hline Australia & 6,759 & 1.49 & 3,049 & 0.67 & 0.73 \\
\hline Spain & 6,444 & 0.9 & 3,320 & 0.47 & 0.62 \\
\hline Taiwan $^{4}$ & 5,904 & 2.05 & 3,673 & 1.30 & 1.40 \\
\hline Swirzerland ${ }^{3}$ & 4,868 & 2.73 & 3,440 & 1.93 & 2.32 \\
\hline Belgium $^{2}$ & 4,271 & 1.84 & 3,213 & 1.33 & 1.70 \\
\hline Finland & 3,652 & 3.09 & 2,530 & 2.14 & 3.19 \\
\hline Dermark & 2,770 & 1.99 & 1,756 & 1.26 & 2.04 \\
\hline Norway & 2,146 & 1.73 & 1,111 & 0.94 & 1.34 \\
\hline Ireland ${ }^{2}$ & 1,084 & 1.39 & 792 & 1.01 & 1.34 \\
\hline Portugal $^{2}$ & 946 & 0.62 & 213 & 0.14 & 0.20 \\
\hline New 7ealand ${ }^{2}$ & 752 & 1.13 & 212 & 0.32 & 0.39 \\
\hline OECD Tocal' & 518,114 & 2.18 & 358,697 & 1.51 & 1.84 \\
\hline Notth America' & 241,869 & 2.22 & 177,369 & 1.67 & 1.98 \\
\hline EU: & 144,990 & I. .81 & 92,269 & 1.15 & 1.54 \\
\hline
\end{tabular}

Note: 1) 1998 2) 1997 3) 1996 4) calculated by average annual exchange rate:

Source: OECD, Main Science and Techmology Indicators 20(0)/2, 2001.

NSC (2000), Indicators of S\&T ROC.

VBS \& MST (2000), China Statistical Yearbook on S\&'T. 


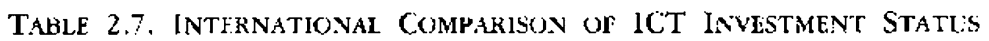

\begin{tabular}{|c|c|c|c|c|c|c|c|}
\hline \multirow[b]{2}{*}{ Ranks } & \multirow[b]{2}{*}{ Country } & \multicolumn{3}{|c|}{1999} & 1992.1999 & 1992.3995 & $1996-19999$ \\
\hline & & $\begin{array}{l}\text { Ratio of } \\
\text { GDP }\end{array}$ & \multicolumn{2}{|c|}{ Expenditure Global Market } & \multicolumn{2}{|c|}{$\begin{array}{l}\text { Compolind Arnual } \\
\text { Grouth Rile }\end{array}$} & $\begin{array}{l}\text { Average } \\
q\end{array}$ \\
\hline 1 & New Zeiland & 10.50 & 6549 & 0.30 & 8.80 & $11.4 !$ & 7.7 .4 \\
\hline 2 & U.K. & 9.30 & $1168+17$ & 5.13 & 6.13 & 4.2 : & 8.50 \\
\hline 3 & Swaten & 9.30 & $2184 \%$ & 1.01 & 2.13 & -1.67 & 1.02 \\
\hline 4 & U.S. & 8.90 & 761.863 & 35.38 & 7.36 & 7.26 & $0.8 i$ \\
\hline 5 & Australia & 8.90 & 36755 & 1.7 & 8.02 & 8.76 & 6.05 \\
\hline 6 & Cislumbia & 8.80 & 86094 & 0.40 & $21.9 ?$ & 11.28 & 28.15 \\
\hline 7 & Canadal & 5.50 & 55345 & 2.57 & 526 & 2.13 & 790 \\
\hline 8 & Crect & 8.50 & 4284 & 0.20 & 13.14 & $0 \% ?$ & 8.5 \\
\hline 9 & Hong Kong & 8.30 & 12772 & 059 & 14.70 & 20.47 & 7.21 \\
\hline 10 & Singaperce & 7.70 & 8025 & 0.37 & 13.13 & $: 9.21$ & $6.5 \%$ \\
\hline 11 & Swritzerland & $: 50$ & 23768 & 1.10 & 3.63 & 3.32 & 3.31 \\
\hline 12 & Isracl & 7.10 & 8322 & 0.39 & 11.21 & $9.5 \%$ & $16, . .5$ \\
\hline 13 & Victmetn & 7.40 & $1 \%$ & 0.08 & 31.49 & 50.20 & 3012 \\
\hline $1 / 4$ & South Africa & 7.20 & $: 0898$ & 0.51 & 7.90 & 10.56 & 5.4 \\
\hline 15 & Japan & $\bar{i} 16$ & 361961 & 16.81 & $8.17 ?$ & 1000 & 6.55 \\
\hline 16 & Hollas.d & $\div .10$ & 32459 & 1.51 & 6.12 & 6.95 & 6.25 \\
\hline 17 & Deturtark & 600 & 33524 & 0.63 & 5.94 & $\therefore ;$ & .63 \\
\hline : & Norwaly & $(0,0)$ & 10.68 & (1) 48 & 3.55 & 5.00 & $5 ?$ \\
\hline$: 9$ & Ireland & 6.50 & 5556 & 0.26 & 9.80 & 9.35 & 969 \\
\hline 20 & Hungiry & 6.40 & 3484 & 0.19 & 16.27 & 7.11 & 27.26 \\
\hline 31 & Malaysia & 5.20 & 5260 & 0. 21 & $10.0 ?$ & $18 .: 9$ & -1.06 \\
\hline 32 & China & 4.90 & 47871 & 222 & 29.19 & 36.80 & 23.84 \\
\hline 31 & Tiuwan & 4.80 & 1601: & U::1 & 10.86 & $56 ?$ & 16.15 \\
\hline 38 & Sourh Kurea & $\therefore(0)$ & 2143 & 1.1 .4 & 7.30 & 15.88 & $-7 .(1)$ \\
\hline
\end{tabular}

Soure: WITSA \& iDC "Digitili Plance 2006: the gheloal information ecrinomy."

'The growth of the global ICT spernding was obvious, at the average annual rate of $7.46 \%$. In the period of $1996-1999$, Taiwan's average annual growth rate of ICT spetuling was 16.45\%. In the peried of 1992-1999, China, Taixan, and India were among the highese growth. The growth rate of Tawan in ICT spending ranked $18^{\text {th }}$, rising from $22^{\text {nal }}$ in 1992 , while: China ranked $10^{\text {th }}$ in 1999 , rising from $19^{\text {th. }}$ in 1992.

\section{(2) Human Capital/Resources}

Oxing to the limitation of definitional difference and data avalability in Tawan, the following indicators, summarized in Table 2.8, are selected to make the intcruational comparison possible: 
TABle 2.8. Summary OF Human CAPITAL INDiCators

\begin{tabular}{|c|c|c|}
\hline Type & Indicators & Source \\
\hline $\begin{array}{l}\text { Citizen Educational } \\
\text { Level }\end{array}$ & $\begin{array}{l}\text { - Educational level of population of age } \\
25-64\end{array}$ & $\begin{array}{l}\text { 1. OECD, Education at Glance } \\
\text { 2. Taiwan-Fukien Demographic Fact } \\
\text { Book, R.O.C. }\end{array}$ \\
\hline $\begin{array}{l}\text { Human Capital } \\
\text { in Labor Force }\end{array}$ & - Education level of workers & $\begin{array}{l}\text { 1. OECD, Employment Outlook } \\
\text { 2. OECD, MSTI database } \\
\text { 3. Yearbook of Manpower Statistics } \\
\text { Taiwan Area, R.O.C. } \\
\text { 4. Employees Survey Report, R.O.C. }\end{array}$ \\
\hline $\begin{array}{l}\text { Human Capital } \\
\text { in } R \& D \\
\text { Personnel }\end{array}$ & $\begin{array}{l}\text { - Total R\&D researchers } \\
\text { - R\&D researchers per } 10 \text { thousand } \\
\text { workers } \\
\text { - Educational level of R\&D researchers }\end{array}$ & $\begin{array}{l}\text { 1. OECD, ANRSE database } \\
\text { 2. OECD, MSTI database } \\
\text { 3. OECD, STI scoreboard } 1999 \\
\text { 4. NSC Indicators of S\&T, ROC }\end{array}$ \\
\hline
\end{tabular}

\section{a. Citizen Educational Level}

As shown in Figure 2.1, citizen of age between 24 and 64 with the degree of college and above accounted for $19.93 \%$ of the total population in Taiwan in 1999, rising from $12.09 \%$ in 1987.

Figure 2.1. Education Attainment of the Population Aged 25-64

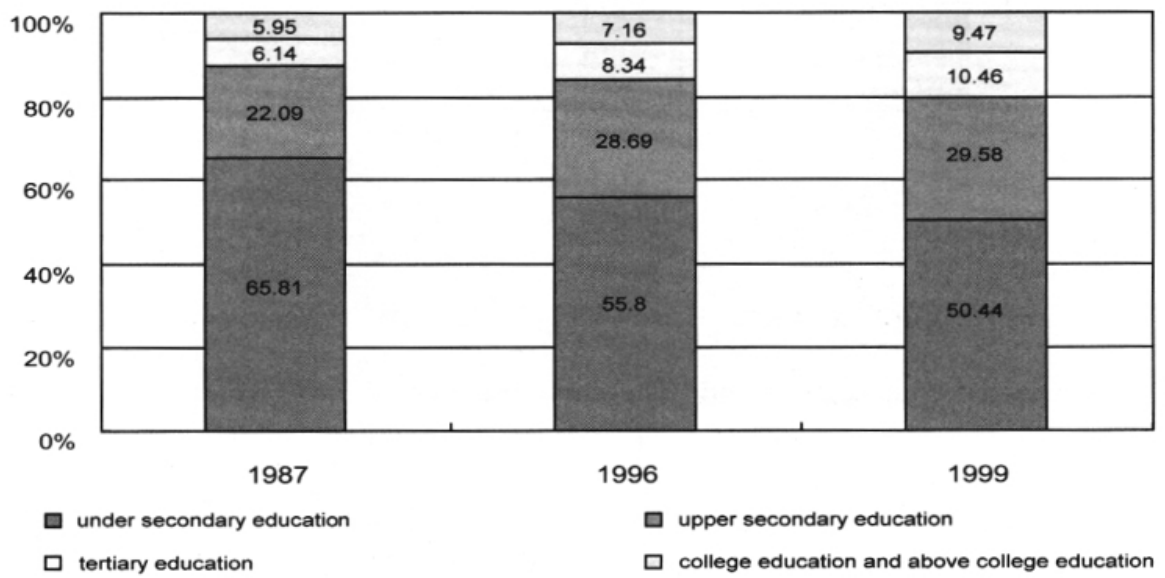

Source: Taiwan-Fukien Demographic Fact Book 2000, Taiwan R.O.C.

In 1996, as shown in Figure 2.2, the overall educational level of Taiwan's population aged between 25 and 64 was lower than that of OECD countries as a whole. There were about $60 \%$ of the total population aged between 25 and 64 who received at least secondary education or higher in OECD countries. In contrast, there were 
only $44 \%$ in Taiwan. Moreover, there were about $13 \%$ (20\% in the U.S.) who received higher education in OECD countries, while only $7.15 \%$ did in Taiwan. The gap of overall educational level between Taiwan and the developed countries was significant.

\section{Figure 2.2. International Comparison of Education Attainment of the} POPUlation Aged 25-64

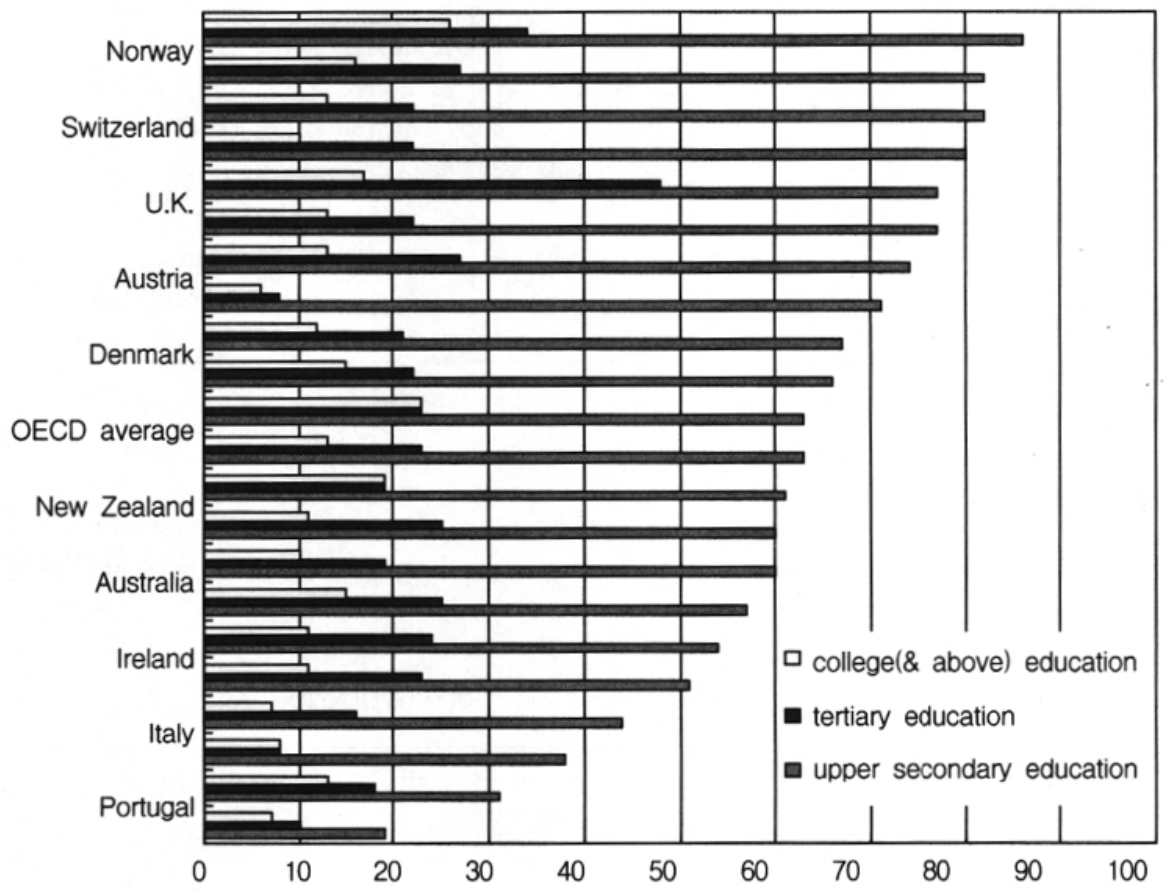

Source: 1. OECD, Education at Glance, 2001.

2. See Figure 2.1.

\section{b. Human Capital in R\&D}

The selected indicators include the total number of $R \& D$ researchers, $R \& D$ researchers full time equivalent (FTE) per 10 thousand in labor force, and the educational level of $R \& D$ researchers.

First of all, in 1999 the R\&D researchers amounted to 88,708 (72,664 by FTE) in Taiwan, rising from 46,173 ( 32,857 by FTE) in 1991 , at the growth rate of 8.64\%, as shown in Figure 2.3. The periods of 1986-1990, 1991-1995, and 1996-1999 all showed about the growth of 1.5 times, revealing the trend of steady growth, as depicted in Figure 2.4. Also, in 1998 the $\mathrm{R} \& \mathrm{D}$ researchers in private business sector amounted to $58 \%$ of the total R\&D researchers, followed by $21.6 \%$ in research institutes and $20 \%$ in universities. The distribution of $R \& D$ researchers in different sectors showed little change over the period of 1989-1999 (see Figure 2.5). 
Figure 2.3. The Trend of R\&D Researcher in TaIWAN

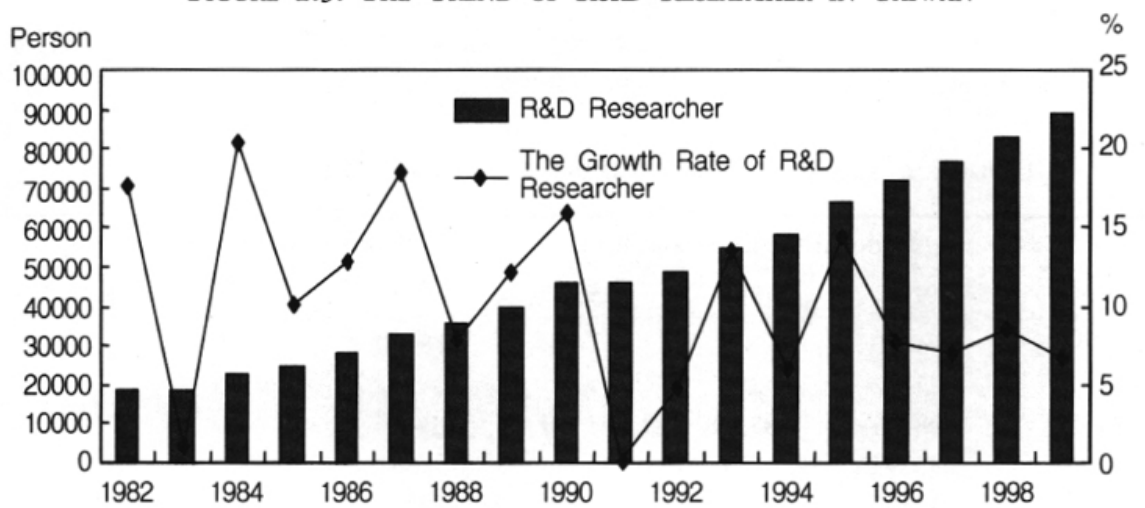

Source: NSC, Indicators of Science and Technology R.O.C., 1995, 2000.

Figure 2.4. The Average Numbers of R\&D Researcher in Three Periods

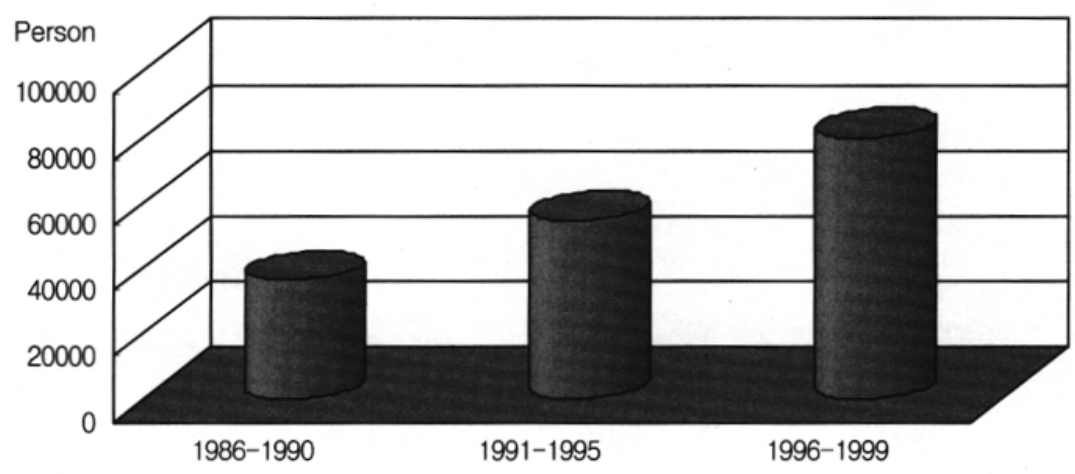

Source: See Figure 2.3.

Figure 2.5. The Structure Change of R\&D Researcher in Tiawan

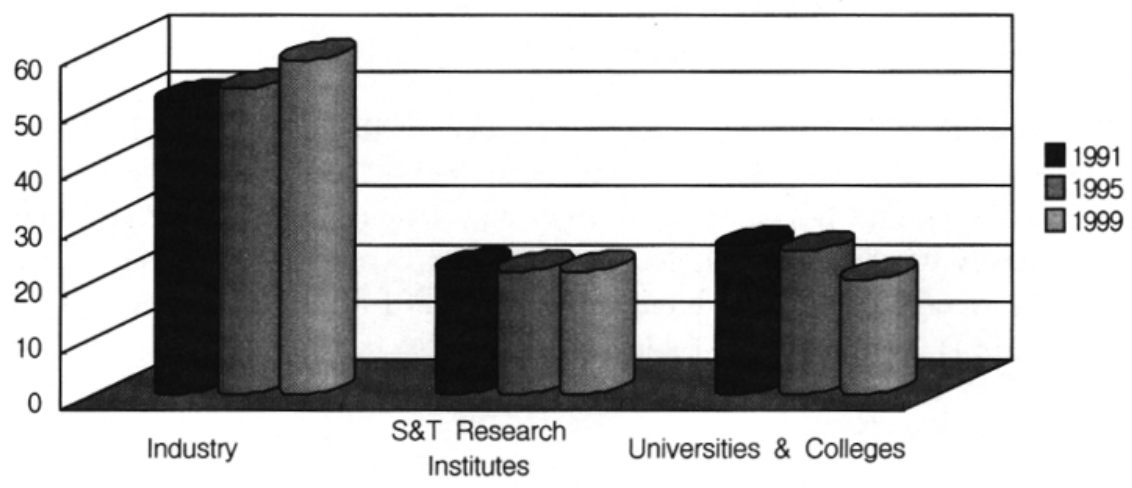

Source: see Figure 2.3. 
In 1998 , the total R\&D researchers by FTE in Taiwan was 71,118 , after the U.S., Japan, China, Germany, U.K., France, South Korea, Canada, and Italy, as shown in Table 2.9.

TABle 2.9. International Comparison of R\&D Personnel (FTE)

\begin{tabular}{|c|c|c|c|c|c|c|}
\hline & \multicolumn{3}{|c|}{ National R\&D Researchers } & \multicolumn{3}{|c|}{ Business R\&D Researchers } \\
\hline & 1997 & 1998 & 1999 & 1997 & 1998 & 1999 \\
\hline U.S. ${ }^{1}$ & 964800 & - & - & 918600 & 974600 & - \\
\hline Japan & 625442 & 652845 & & 404232 & 429195 & - \\
\hline China & 588700 & 485500 & $\$ 31100$ & - & - & - \\
\hline Germany & 235793 & 237712 & - & 132687 & 133529 & \\
\hline France & 155302 & - & - & 70698 & - & - \\
\hline U.K. & 146546 & 158671 & - & 83600 & 92280 & - \\
\hline South Korea & 102660 & - & - & 69871 & - & - \\
\hline $\mathrm{Canada}^{2}$ & 84583 & - & - & 46130 & - & - \\
\hline Italy & 76056 & - & - & 27612 & - & - \\
\hline Taiwan & 64580 & 71118 & 72664 & 39221 & 43903 & 46192 \\
\hline Australia & - & 62250 & - & 14400 & 14087 & \\
\hline Spain & 53883 & 60269 & - & 12009 & 13902 & - \\
\hline Netherlands & 38055 & 39081 & - & 17302 & 18164 & - \\
\hline Sweden & 36878 & - & - & 20924 & - & - \\
\hline Belgium & 23486 & - & - & 11805 & - & - \\
\hline Finland & 21149 & 23745 & & 8675 & 9689 & - \\
\hline Norway & 17490 & - & - & 9348 & - & - \\
\hline Denmark & 17443 & - & - & 7522 & - & - \\
\hline Portugal & 13607 & - & - & 1193 & - & - \\
\hline New Zealand & 8264 & - & - & 1692 & - & - \\
\hline Ireland & 7825 & - & - & 5098 & - & - \\
\hline
\end{tabular}

Note: 1. The latest data of national R\&D researchers for the U.S is in 1993, Business R\&D researchers in 1997.

2. The latest data of national R\&D researchers for Canada is in 1995 .

3. Business $R \& D$ researchers in China are calculated by FTE.

Source: See Table 2.6 .

The number of R\&D researchers by FTE per 10 thousand in the labor force in Taiwan in 1999 was 75, raised from 38.4 in 1991, as shown in Figure 2.6. Compared with OECD countries, in 1999 only four countries including Japan's 96, Finland's 94, Sweden's 84, Norway's 76 had better rankings than Taiwan. As for the average annual growth rate in the period of 1991-1998, Taiwan's $10.22 \%$ led all OECD countries (see Table 2.10).

(3) Knowledge Diffusion

The selected indicators and associated references are summarized in Table 2.11: 
Figure 2.6. R\&D ReSEARCHERS PER 10 THOUSAND LABOUR ForCE IN TAIWAN

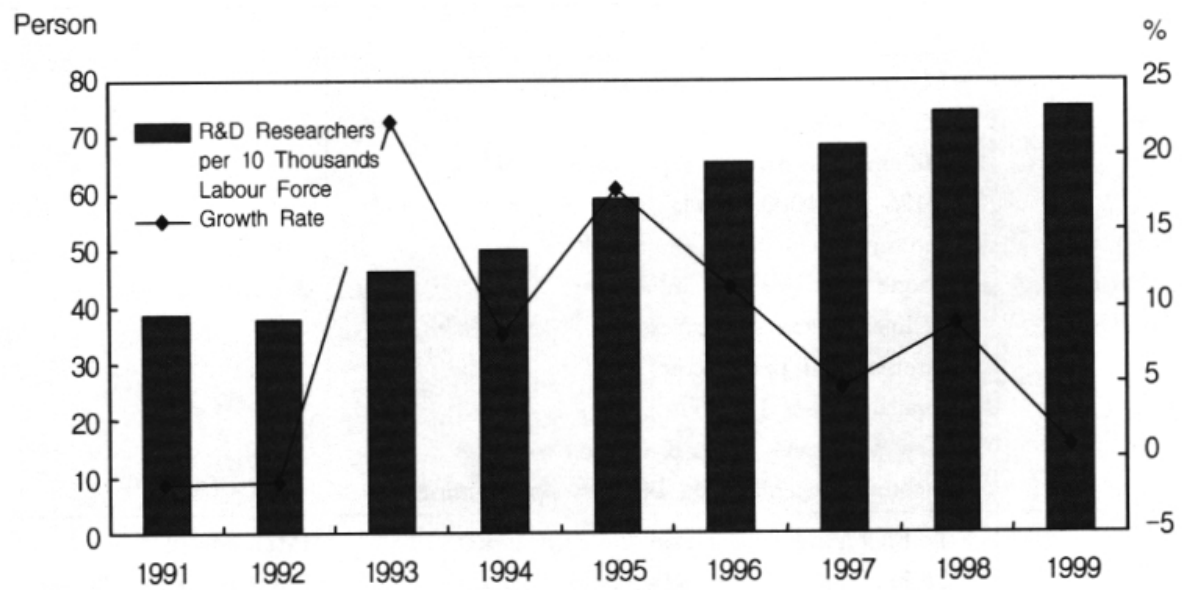

Source: See Figure 2.3.

TABle 2.10. R\&D RESEARCHERS (FTE) PER 10 THOUSAND LABOUR FORCE

\begin{tabular}{|c|c|c|c|c|}
\hline & 1981 & 1991 & 1998 & Average Growth Rate \\
\hline Japan & 69 & 92 & 96 & 0.61 \\
\hline Finland & - & 55 & 94 & 7.96 \\
\hline Sweden $^{1}$ & 41 & 59 & 84 & 6.06 \\
\hline Norway $^{1}$ & 38 & 63 & 76 & 3.18 \\
\hline Taiwan & 25 & 38 & 75 & 10.22 \\
\hline U.S. ${ }^{3}$ & 62 & 75 & 74 & -0.67 \\
\hline Australia & 35 & 55 & 67 & 2.86 \\
\hline Denmark $^{1}$ & 25 & 41 & 61 & 6.85 \\
\hline Germany & 44 & 61 & 60 & -0.24 \\
\hline France $^{1}$ & 36 & 52 & 60 & 2.41 \\
\hline Canada $^{1}$ & 31 & 46 & 57 & 3.64 \\
\hline U.K. & 47 & 45 & 55 & 2.91 \\
\hline Switzerland ${ }^{2}$ & - & 45 & 55 & 4.10 \\
\hline Belgium $^{1}$ & 31 & 43 & 54 & 3.87 \\
\hline Ireland $^{1}$ & 17 & 39 & 51 & 4.57 \\
\hline Netherlands & 34 & 40 & 50 & 3.24 \\
\hline South Korea ${ }^{1}$ & 14 & 40 & 47 & 2.72 \\
\hline New Zealand ${ }^{1}$ & 34 & 40 & 44 & 1.60 \\
\hline Spain & 14 & 26 & 37 & 5.17 \\
\hline Italy $^{1}$ & 23 & 31 & 32 & 0.53 \\
\hline Portugal $^{1}$ & 7 & 12 & 27 & 14.47 \\
\hline China & - & 20 & 21 & 0.70 \\
\hline
\end{tabular}

Notes: 1: 1997; 2: 1996; 3: 1993.

Source: See Table 2.14 . 
TABle 2.11. Summary OF KNOWLedge Diffusion Indicators

\begin{tabular}{l|l|l}
\hline \multicolumn{1}{c|}{ Types } & \multicolumn{1}{c}{ Indicators } & Source \\
\hline & - PC in use & \\
& - PC per 1000 people & \\
& - Million of instructions per second (MIPS) & \\
- MIPS per 1000 people & IMD Computer Industry \\
ICT & - Internet users per 1000 people & Almanac database (2001) \\
Infrastructure & - Phone lines per 100 inhabitants & \\
and Use & - Cellular phone subscribers per 1000 inhabitants & \\
& - International phone costs & \\
& - Availability of IT skills & \\
\hline Social & - New IT meets business requirement & IMD Global \\
Innovation & - E-commerce enhancing business opportunities & Competitiveness Report \\
Capital & - Technological cooperation between firms & \\
\hline & Calues of society (hard work, innovation) support & 2000-2001 \\
\hline
\end{tabular}

a. ICT Infrastructure and Use

Under the consideration of data availability and comparability, in this paper some indicators used by IMD in its Global Competitiveness. Report are chosen as follows:

- PC in use (\% of world total). Among the 49 countries reported by IMD's Computer Industry Almanac, in 2001 Taiwan's $1.38 \%$ ranked $14^{\text {th }}$, rising from the $16^{\text {th }}$ in 2000. In Asia, only Japan, China, and South Korea ranked better in 2001. The first 5 countries were the U.S., Japan, Germany, U.K., and France in the ranking order.

- PC per 1000 people. In 2001 Taiwan's 336 ranked $22^{\text {nd }}$, rising from 226 in 2000. In Asia, only Singapore's 440 and Japan's 414 ranked better in 2001. Apart from the Asian countries, the U.S., Sweden, Finland, Norway, and Denmark were among the top.

- Million of instructions per second (MIPS). In 2001 Taiwan ranked $17^{\text {th }}$, following after Japan, China, and South Korea among the Asian countries. On the whole, the U.S., Japan, Germany, U.K., and France were among the top five, and the U.S. alone amounted to $35.63 \%$ of the world total.

- MIPS per 1000 people. In 2001 Taiwan ranked $23^{\text {rd }}$, ranking after Singapore (the $11^{\text {th }}$ ) and Japan (the $19^{\text {th }}$ ) among the Asian countries. On the whole, the U.S. ranked still the first. 
- Internet users per 1000 people. In 2001 Taiwan's 314 ranked $15^{\text {th }}$, ranking after South Korea's 402 (ranking $7^{\text {th }}$ ) and Hong Kong's 324 (ranking $14^{\text {th }}$ ) among the Asian countries. On the whole, Canada's 501, Sweden's 496, Norway's 490, the U.S.'s 488 , Denmark's 487, Finland's 462, and South Korea were among the top.

- Phonc lines per 1000 inhabirants. In 2001 Taiwan's 598 ranked $12^{\text {th }}$, ranking the first among the Asian countries. On the whole, Norway, the U.S., Swiss, Denmark, and Sweden were among the top five.

- Cellular phone subscribers per 1000 inbabitants. In 2001 Taiwan's 750 ranked $2^{\text {nd }}$, shared with Austria, followed by Hong Kong's 749.4. Finland ranked the first.

- International phone costs. The higher the international phone costs, the more people could nor afford to use the related facilities. Hence, in IMD's reports, higher international costs lead to the lower ranks. In 2001 , Taiwan ranked $35^{\text {th }}$, falling from the $29^{\text {th }}$ in 2000 . On the whole, Swiss, Netherlands, Germany, Norway, and the U.S. ranked the top five.

- Availability of IT skills. In 200l, Taiwan ranked $12^{\text {th }}$, falling from the $8^{\text {th }}$ in 2000, ranking after Singapore among the Asian countrics. On the whole, North European countries and the U.S. led all the other countries.

- New IT meets husiness requirement. In 200 ), Taiwan ranked $20^{\text {th }}$, falling from the $16^{\text {th }}$ in 2000 , ranking after Singapore among the Asian countries. On the whole, Finland, Sweden, Singaporc, the U.S., and Canada ranked the top five.

- E-commerce enhancing business opportunities. In 2001, Taiwan ranked $18^{\text {th }}$, falling from the $12^{\text {th }}$ in 2000 , ranking after Singapore and Hong Kong among the Asian countries. On the whole, Finland, the U.S., Sweden, Singapore, and Australia ranked the rope five.

\section{b. Social Innovation Capital}

Indicators of this category are still at their early stage. In this paper, "technological cooperation between firms," "technological transfer between firms and the academia," and "values of sociery (hard work, innovation) support competiriveness" used by IMD in its Global Competitiveness Report are chosen for measuring the degree of knowledge diffusion.

As shown in Table 2.12, in 2001 Taiwan ranked $10^{\text {th }}$ for technological conperation between firms, rising from the $12^{\text {th }}$ in 2000 , ranking after Japan (the $8^{\text {th }}$ ) and Singapore (the $9^{\text {th }}$ ) among the Asian countries. On the whole, Finland, Sweden, Israel, the 
U.S., and Iceland ranked the top five. For technological transfer between firms and the academia, in 2001 Taiwan ranked $12^{\text {th }}$, falling from the $11^{\text {th }}$ in 2000 , nevertheless in Asia ranking the first. On the whole, Fintand, Israel, the L.S.. Singapore, and Ireland ranked the tup five. Finally, for the social values, in 2001 Taiwan ranked $9^{\text {th }}$, rising from the $10^{\text {th }}$ in 2000, ranking the first among the Asian countries. On the whok, Singapore, the L.S., Jceland, Finland, and Hong Kong ranked the top five as in the previous year.

Table 2.12. International Comparison of social innovation Capital

\begin{tabular}{|c|c|c|c|c|c|c|c|c|c|}
\hline \multirow{2}{*}{$\begin{array}{l}\text { IMD } \\
\text { Rark }\end{array}$} & \multirow{2}{*}{$\begin{array}{l}\text { Score } \\
\text { ountries }\end{array}$} & \multicolumn{2}{|c|}{$\begin{array}{l}\text { Inter-firm } \\
\text { Tech-cosop }\end{array}$} & \multicolumn{2}{|c|}{$\begin{array}{c}\text { Tech-Industry- } \\
\text { Academia } \\
\text { Tech-coop }\end{array}$} & \multirow{2}{*}{$\begin{array}{l}\text { Sorial } \\
2000\end{array}$} & \multirow{2}{*}{$\begin{array}{l}\text { Values } \\
2001\end{array}$} & Composite & \multirow{2}{*}{$\begin{array}{l}\text { index } \\
2001\end{array}$} \\
\hline & & 2000 & 2001 & 2000 & 2001 & & & 2000 & \\
\hline 1 & Finland & 7.0120 & 7.7010 & 6.91 .10 & 7.6800 & 8.2220 & 82720 & 7.3827 & 7.8853 \\
\hline 2 & L:S. & 6.3330 & 0.6780 & 6.5400 & 6.6500 & 8.1920 & 8.3800 & 7.0217 & 7.2360 \\
\hline$\alpha$ & Israel & 6.8460 & 6.7270 & 5.8850 & 7.3500 & 7.2160 & 6.9700 & 6.6450 & 7.0157 \\
\hline 4 & Singapore & 6.1640 & 6.00000 & 6.0330 & 6.1500 & 8.210 & 8.5070 & 6.9727 & 6.8857 \\
\hline 5 & Iceland & 6.4000 & 6.3330 & 5.3600 & 5.3301 .1 & 8.2400 & 8.3330 & $6.666,77$ & 6.6653 \\
\hline 6 & Sweden & 6.1580 & 6.8180 & 5.6580 & 5.5800 & 6.2370 & 6.8790 & 6.0177 & 6.1457 \\
\hline $\bar{i}$ & Canada & 6.0320 & 6.0750 & 5.1290 & 5.5000 & 7.1940 & .5610 & 6.1183 & $6.3(1) 87$ \\
\hline 8 & Netherlands & 6.4940 & 6.1450 & 5.9750 & 5.5600 & 7.5370 & 7.3800 & 6.6687 & 6.3647 \\
\hline 9 & Ausiralia & 5.1340 & 5.8140 & $3.0 \div 10$ & 5.3200 & 7.0000 & $? .8140$ & $5.221 \%$ & 6.3160 \\
\hline 10 & Irtlard & 5.6000 & 5.6070 & $5.4(30)$ & 3.8900 & 760,70 & $=4200$ & $(1.2223$ & $6.30 \times 8 ?$ \\
\hline 11 & Switzerland & 6.2240 & 5.6360 & 5.7960 & 5.7300 & $? \cdot P)(1)$ & $? .3860$ & 606053 & 0.2507 \\
\hline 12 & Taiwan & 5.94300 & 6.0000 & 5.2670 & 5.1800 & 7.3330 & 7.4430 & 6.1667 & 6.2077 \\
\hline 13 & Austria & 5.1000 & 5.5600 & 4.8000 & 5.1000 & 6.7670 & .5200 & $5.553 ?$ & 6.6600 \\
\hline 14 & Germany & 6.2350 & 5.8700 & 5.3410 & 5.1400 & 6.8240 & $(0.8050$ & 6.1333 & 5.9383 \\
\hline 15 & Hong Kong & 4.4680 & 5.0950 & 3.8300 & 1.4400 & 8.4580 & 8.1950 & 5.5853 & 5.9100 \\
\hline 16 & Deninark & 5.7010 & 5.4080 & 4.8510 & 5.0700 & 0.4600 & $6.39: 40$ & 36707 & 5.6240 \\
\hline $1 ?$ & Belgium & 5.6000 & 5.3130 & 5.0250 & .8 .8200 & 6.9000 & 6.42 .40 & 5.8417 & 5.5190 \\
\hline 18 & Soutin Korea & 3.9430 & 4.1690 & 4.1140 & 4,5600 & 8.1140 & 7.3240 & 5.3903 & 5.5510 \\
\hline 20 & U.K.K. & 4.9600 & 5.1080 & $4.4(30)$ & 4.2200 & 6.5800 & $6.38 \div 0$ & $5.3: 33$ & 5.2363 \\
\hline 22 & Japan & 6.0810 & 6.0100 & 3.9590 & 3.6000 & 7.0010 & 3.6150 & 5.7037 & 5.0780 \\
\hline 23 & Nontay & 5.2330 & 4.8480 & 4. 5670 & $1 . ! 100$ & 6.0000 & 6.2370 & 5.iving & 500650 \\
\hline $2 \cdot 1$ & Veu Zealand & 5.26 .30 & 5.1540 & 4.3800 & (10) 100 & 6.5000 & 5.8870 & 5.3830 & $5 .(1270$ \\
\hline 28 & Spain & 4.3140 & 4.3480 & 3.2290 & 3.2500 & 5.5070 & 7.0720 & $4.350(x)$ & f. $x(x)(x)$ \\
\hline 29) & Malaysia & 4.2570 & 4.7750 & 3.5440 & 3.8300 & 7.2570 & 6.2250 & 503,300 & 4.733 \\
\hline 30 & France & 5.3850 & 4.960 & 4.3520 & 3.8700 & 5.3190 & 5.3550 & $5.018 ?$ & 1.2237 \\
\hline 34 & Chaina & 3.9330 & 3.1870 & $3.5: 80$ & 2.9200 & 7.0670 & $\because .40>0$ & 9.8593 & 1.50.保? \\
\hline 42 & Portugal & 36670 & 3.3960 & $2.96,30$ & 2.9100 & $S .7(1)$ & 57780 & $4.1: 13$ & 4.0280 \\
\hline $4 j$ & Iraly & 4.1410 & 3.7690 & 28960 & $2.700)$ & 5.8500 & $5.4100\}$ & A.74(6) & 3.7830 \\
\hline
\end{tabular}

Note: Conposite index is the average of the above three scores.

Source: IMD. "The World Competitiveness Yearisurk." $20000-2001$. 
Overall ranking can be obrained by the average of the above three rankings. In 2001, Taiwan ranked $12^{\text {th }}$, falling from the $9^{\text {th }}$ in 2000 . On the whole, Finland, the U.S., Israel, Singapore, Iceland, Sweden, Canada, Netherlands, Australia, Swiss, and Ireland ranked higher than Taiwan.

(4) Institutional Settings for Knowledge Diffusion

Also based on IMD report, the selected indicarors include the degree of intellectual property protection, legal settings for technological development and application, financial setrings for technological $R \& D$, and availability of venture capital. The measurement is summarized in Table 2.13.

Table 2.13. INTERNational Comparison of InNovation Seetings

\begin{tabular}{|c|c|c|c|c|c|c|c|c|c|c|c|}
\hline \multicolumn{2}{|r|}{ Score } & \multicolumn{2}{|c|}{ IP Protection } & Legal & Settings & \multicolumn{2}{|c|}{$\begin{array}{l}\text { Financial } \\
\text { Settings }\end{array}$} & \multicolumn{2}{|c|}{$\begin{array}{c}\text { Venture Capital } \\
\text { Availability }\end{array}$} & \multicolumn{2}{|c|}{$\begin{array}{l}\text { Composite } \\
\text { Index }\end{array}$} \\
\hline Rank & Countries & 2000 & 2001 & 2000 & 2001 & 2000 & 2001 & 2000 & 2001 & 2000 & 2001 \\
\hline 1 & Finland & 8.750 & 8.642 & 8.074 & 8.325 & 7.605 & 7.375 & 7.605 & 7.392 & 8.009 & 7.934 \\
\hline 2 & U.S. & 8.762 & 9.091 & 7.228 & 7.567 & 7.127 & 6.756 & 8.619 & 8.117 & 7.934 & 7.883 \\
\hline 3 & Sweden & 8.026 & 8.182 & 7.079 & 7.631 & 6.632 & 6.758 & 7.263 & 7.333 & 7.250 & 7.476 \\
\hline 4 & Netherlands & 8.840 & 8.514 & 7.316 & 7.159 & 6.840 & 6.441 & 7.951 & 7.583 & 7.737 & 7.424 \\
\hline 5 & Israel & 3.077 & 7.333 & 7.269 & 7.758 & 6.346 & 6.606 & 7.764 & 7.765 & 7.115 & 7.366 \\
\hline 6 & Ireland & 8.400 & 8.1 .15 & 7.333 & 7.429 & 6.467 & 6.321 & 6.847 & 6.893 & 7.262 & 7.197 \\
\hline 7 & Singapore & 8.131 & 8.060 & 8.164 & 7.758 & 6.984 & 6.328 & 7.049 & 6.358 & 7.582 & 7.126 \\
\hline 8 & Germany & 9.153 & 8.494 & 6.612 & 6.857 & 6.847 & 6.571 & 6.118 & 6.545 & 7.183 & 7.117 \\
\hline 9 & Den & 8.575 & 8.338 & 6.989 & 6.535 & 6.506 & 6.200 & 6.138 & 6.732 & 7.052 & 6.951 \\
\hline 10 & Canada & 8.548 & 8.658 & 6.742 & 7.358 & 5.129 & 5.185 & 6.516 & 6.488 & 6.734 & 6.922 \\
\hline 11 & Switzerland & 8.980 & 8.759 & 7.143 & 7.310 & 5.531 & 6.409 & 4.857 & 5.114 & 6.878 & 6.898 \\
\hline 12 & Austr & 8.887 & 8.628 & 6.887 & 7.318 & 5.175 & 4.907 & 5.583 & 5.835 & 6.633 & 6.672 \\
\hline 13 & Austria & 8.933 & 8.520 & 6.633 & 6.680 & 5.23 .3 & 5.100 & 4.167 & 5.520 & 6.242 & 6.530 \\
\hline 14 & Belgium & 7.975 & 7.254 & 6.100 & 6.388 & 5.500 & $5.09 \mathrm{I}$ & 5.650 & 6.492 & 6.306 & 6.306 \\
\hline 15 & Iceland & 7.920 & 7.333 & 6.800 & 6.500 & 5.760 & 5.333 & 5.920 & 6.000 & 6.600 & 6.292 \\
\hline 16 & Luxembo & 8.074 & 7.789 & 6.889 & 6.526 & 6.000 & 5.263 & 5.333 & 5.474 & 6.574 & 6.263 \\
\hline 17 & U.K. & 8.720 & 8.238 & 6.440 & 6.071 & 4.520 & 4.238 & 6.970 & 6.415 & 6.663 & 6.241 \\
\hline 18 & Taiwan & 6.867 & 7.038 & 6.687 & 6.380 & 5.233 & 5.063 & 7.133 & 6.354 & 6.480 & 6.209 \\
\hline 19) & France & 8.267 & 7842 & 6.418 & 5.785 & 5.582 & 5.312 & 5.685 & 5.739 & 6.488 & 6.182 \\
\hline 20 & Hong Kong & 5.833 & 6.143 & 6.875 & 6.667 & 5.833 & 4.550 & 6.792 & 6.829 & 6.333 & 6.047 \\
\hline 21 & New Zealand & 8.175 & 8.692 & 6.737 & 6.154 & 4.211 & 4.077 & 4.035 & 4.755 & 5.790 & 5.920 \\
\hline 22 & Norway & 8.567 & 7.652 & 6.800 & 5.670 & 6.506 & 4.440 & 6.400 & 5.870 & 7.068 & 5.908 \\
\hline 23 & Japan & 7.394 & 7.500 & 6.184 & 6.192 & 5.143 & 5.301 & 3.320 & 3.569 & 5.510 & 5.641 \\
\hline 24 & South Africa & 7.000 & 6.753 & 6.100 & 6.494 & 3.567 & 3.684 & 5.051 & 4.442 & 5.430 & 5.343 \\
\hline 25 & Spain & 6.943 & 6.058 & 5.686 & 5.652 & 4.257 & 4.029 & 4.600 & 4.824 & 5.372 & 5.141 \\
\hline
\end{tabular}

Source: See Table 2.12. 
For the degree of intellectual property protection, in 2001 Taiwan ranked $23^{\text {r. }}$, rising from the $28^{\text {th }}$ in 2000 . On the whole, leading countries included the U.S., Swiss, New Zealand, Canada, and Finland.

For the legal sectings for technological development and application, in 2001 Tawan ranked $20^{\text {ti }}$, falling from the $17^{\text {th }}$ in 2000 . On the whoke. leading countries included Finland, Isratel, Singapore, Sweden, and the U.S.

For the financial settings for technological R\&I), in 2001 Taiwan ranked $18^{\text {th }}$, ranking after Singapore and Japan among the Asian countries. On the whole, leading countries included Finland, Sweden, the U.S., Isracl, and Germany.

Finally, for the availability of venture capital, in 2001 Taiwan ranked $14^{\text {th }}$, falling from the $6^{\text {th }}$ in 2000, ranking after Hong Kong and Singapore among the Asian countries. On the whole, leading countries included the U.S., Israel, Netherlands, Finland, and Sweden.

likewise, overall ranking can be obtained by the average of the above scores. In 2001. Taiwan ranked $18^{\text {ih }}$, the same as in 2000 . On the whole, Finland, the U.S., Sweden, Netherlands, Israel, Irdand, Singapore, and Germany were among the leading countrics.

(5) Direct Knowledge Output and Knowledge Applicarion

Ihe selected indicators for direct knowledge output and knowledge application are summarized in Table 2.14.

TABlE 2.14. SIMMMARY OF KNOWLEDGE OIJPLT INDICATORS

\begin{tabular}{|c|c|c|}
\hline lype & Indicators & Suurce \\
\hline $\begin{array}{l}\text { Direct } \\
\text { Knowledge } \\
\text { Outpur }\end{array}$ & $\begin{array}{l}\text { 1. SCI Publicatiouss } \\
\text { 2. EI Publications } \\
\text { 3. Eatents Granted in the IS.S. }\end{array}$ & 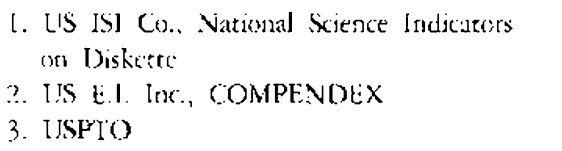 \\
\hline \multirow{3}{*}{$\begin{array}{l}\text { Knowledgc } \\
\text { Application }\end{array}$} & i. Export Composition & $\begin{array}{l}\text { 1. OECD, STAN Database } \\
\text { 2. Imurere and biport Nagertic Iape, RO.C. }\end{array}$ \\
\hline & 2. Industrial Composition & 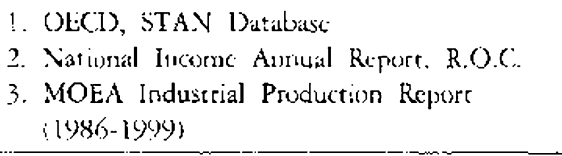 \\
\hline & $\begin{array}{l}\text { 3. Employment of Knowledge } \\
\text { Workers }\end{array}$ & $\begin{array}{l}\text { 1. Yearbook of Manpower Scatistics Taiwan } \\
\text { Area, RoC... } \\
\text { 2. APEC. Towards Knowledge-Based } \\
\text { Econumics In APEC l2000. Of } \\
\text { 3. OtCD, STAN Database }\end{array}$ \\
\hline
\end{tabular}

a. The Number of Publications on $\mathrm{SCI}$

In 1999, Iaiwan's number of publications on SC.I amounted to 8,931 , ranking 
$19^{\text {th }}$, the same ranking as in 1998 , but increased in quantity from 8,601 , as shown in Table 2.15. The first 10 countries in the ranking order were the U.S., Japan, U.K., Germany, France, Canada, Italy, Russia, Australia, and Spain. China ranked $11^{\text {th }}$ in 1994 , rising from the $12^{\text {th }}$ in 1998 .

As shown in Table 2.15, for the number of publications on SCl per capita, in 1999 'Taiwan's 405 ranked $15^{\text {th }}$. On the whole, the leading countries werc Swiss (1,904), followed by Sweden, Israel, U.K., Netherlands, Australia, Canada, Belgium, the U.S., and France.

Table 2.15. International Comparison of SCI and EI Publications

\begin{tabular}{|c|c|c|c|c|c|c|c|c|c|}
\hline \multirow{3}{*}{ Nation } & \multicolumn{4}{|c|}{$\mathrm{SCI}$} & \multirow{3}{*}{ Nation } & \multicolumn{4}{|c|}{ EI } \\
\hline & \multicolumn{2}{|c|}{1999} & \multicolumn{2}{|c|}{1998} & & \multicolumn{2}{|c|}{1999} & \multicolumn{2}{|c|}{1998} \\
\hline & Amount & Rank & Amount & Rank & & Amount & Rank & Amount & Rank \\
\hline U.S. & 245,281 & 1 & 244,654 & 1 & U.S. & 53,099 & 1 & 52,369 & 1 \\
\hline Japan & 68,684 & 2 & 66,832 & 2 & Japan & 21,451 & 2 & 19,128 & 2 \\
\hline U.K. & 67,069 & 3 & 65,494 & 3 & China & 11.347 & 3 & 12,584 & 3 \\
\hline Germany & 63,257 & 4 & 62,787 & 4 & L.K. & 11,001 & 4 & 11,280 & 4 \\
\hline France & 46,337 & 5 & 45,434 & 5 & Germany & 10,775 & 5 & 9,856 & 5 \\
\hline Canada & $32,65 ?$ & 6 & 31,666 & 6 & France & 7,860 & 6 & 7,366 & 6 \\
\hline Italy & 29,314 & 7 & 28,793 & 7 & Canada & 6,081 & 7 & 6,237 & 7 \\
\hline Russia & 24,492 & 8 & 24,765 & 8 & Iraly & 5,304 & 8 & 5,084 & 8 \\
\hline Australja & 20,682 & 9 & 20,066 & 9 & Russia & 4,991 & 9 & 4,015 & 10 \\
\hline Spain & 20,650 & 10 & 19,424 & 10 & South Korea & 4,777 & 10 & 3,645 & 11 \\
\hline China & 19,849 & 11 & 16,612 & 12 & Tawan & 4,376 & 11 & 4,026 & ) \\
\hline Netherlands & 18,042 & 12 & 18,116 & 111 & Inetia & 4,333 & 12 & 3,613 & 12 \\
\hline India & 16,046 & 13 & 14,923 & 13 & Australia & 3,328 & 13 & 3,176 & 13 \\
\hline Sweden & 14,675 & 14 & 14,356 & 14 & Spain & 3,266 & 14 & 2,928 & 14 \\
\hline Switzerland & 13.576 & 15 & 13,001 & 15 & Netherlands & 2,666 & 15 & 2,582 & 15 \\
\hline South Korea & 10,992 & 19 & 9,503 & 16 & Sweden & 2,615 & 16 & 2,533 & 16 \\
\hline Belgiurn & 9,651 & 17 & 9,321 & 17 & Brazil & 2,022 & 17 & 1,628 & 18 \\
\hline Brazil & 8,941 & 18 & 7,918 & 20 & Poland & 1.993 & 18 & 1,558 & 19 \\
\hline Taiwan & 8,931 & 19 & 8,601 & 19 & Singpore & 1,854 & 19 & 1,213 & 23 \\
\hline Israel & 8,686 & 20 & 8,806 & 18 & Switzerland & 1,809 & 20 & 1,680 & 17 \\
\hline
\end{tabular}

Source: NSC (200()), Indicastors of S\&T.

\section{b. The Number of Publications on $\mathbf{E I}$}

In 1999, Taiwan's number of publications on EI amounted to 4,376, ranking $11^{\text {th }}$, falling from 9th in 1998 , but increased in quantity from 4,026, as shown in Table 2.15. The first 10 councries in the ranking order were the U.S., Japan, China, U.K., Germany, France, Canada, Italy, Russia, and South Korea. As for the number of publications on EI per capita, as shown in Table 2.15, in 1999 Taiwan's 199 ranked $5^{\text {th }}$, following after Singapore, Sweden, Swiss, and Canada. The relative strength of 
Taiwan in engineering research is significant.

c. The Number of Patents Granted in the U.S.

In 1999. Taiwan's number of patents granted in the U.S. amounted to 5,806 , rising from 4,667 in 1998 and ranked $4^{\text {h }}$, the same ranking as in 1998 , ranking after the U.S., Japan, and Germany, as shown in Table 2.16. As for the number of patents granted in the U.S. per capita, in 1999 Taiwan's 261 ranked the second, after the U.S. The relative strength of Tajwan in the U.S.-granting patents, at least in quantiry, is even more significant.

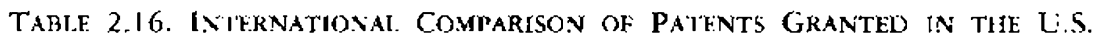

\begin{tabular}{|c|c|c|c|c|c|c|c|c|c|}
\hline \multirow{3}{*}{ Nation } & \multicolumn{4}{|c|}{$\begin{array}{l}\text { Patents Granted in the U.S. } \\
\text { (all rypes) }\end{array}$} & \multirow{3}{*}{ Nation } & \multicolumn{4}{|c|}{$\begin{array}{l}\text { Patents Granted in the U.S. } \\
\text { (Inventions) }\end{array}$} \\
\hline & \multicolumn{2}{|c|}{2000} & \multicolumn{2}{|c|}{1949} & & \multicolumn{2}{|c|}{$20(x)$} & \multicolumn{2}{|c|}{1999} \\
\hline & Number & Kank & Num ber & Rank & & Number & Rank & Number & Rank \\
\hline World & $176,(187$ & - & 169,146 & - & World & 157,497 & - & 153,485 & - \\
\hline U.S. & $y 7,0 ! 6$ & 1 & 94.090 & 1 & L'S. & 85,072 & $\vdots$ & 83,905 & 1 \\
\hline J:ıрап & $32.92-4$ & 2 & 32,514 & $\underline{2}$ & Japan & 31,296 & 2 & 31,104 & $?$ \\
\hline Germany & 10,822 & 3 & 9,805 & 3 & Germany & 10,234 & 3 & 9,327 & 3 \\
\hline Taiwan & 5,806 & 4 & 1,526 & 4 & Tuiwan & $4,66 ?$ & 4 & 3.643 & 5 \\
\hline France & 4,173 & 5 & 4.097 & 5 & France & 3.819 & 5 & 3,820 & 4 \\
\hline Li.K. & $4,(390)$ & 6 & 3,900 & 6 & $U, K$ & 3.667 & 6 & 3,572 & 6 \\
\hline Cunasta & 3.925 & $?$ & $3,6: 8$ & 8 & Canata & 3,119 & 7 & 3,226 & 8 \\
\hline South Korea & $3,47 ?$ & 8 & 3.679 & 7 & Sout'r Korea & 3.314 & 8 & 3,562 & $?$ \\
\hline Italy & 1,967 & 9 & 1,686 & 9 & Italy & 1,714 & 9 & 1,492 & 9) \\
\hline Sweden & 1,738 & 10 & 1,542 & 10 & Sweden & $:, 577$ & 10 & 1,401 & 10 \\
\hline Switzerlatud & 1,458 & 11 & 1.390 & 12 & Switzerland & i,323 & $: 1$ & 1,279 & 11 \\
\hline Netherlands & 1,110 & 12 & 1,396 & 31 & Nerberlands & $1,2+1$ & 12 & 1,24 & 12 \\
\hline Australia & 859 & 13 & 832 & 13 & Istacl & 783 & 13 & $7 / 1^{2}$ & 13 \\
\hline Israel & 8.56 & 14 & 792 & 14 & Aastralia & 704 & $: 4$ & $70 ?$ & 14 \\
\hline Belfium & 756 & 15 & $7 ! 8$ & 13 & Bclgium & 694 & 15 & 648 & 16 \\
\hline Finland & 649 & 19 & 695 & 15 & Finland & 618 & 16 & 649 & 15 \\
\hline Hong Kong & 348 & 17 & 413 & 1) & A:Istria & 505 & $i:$ & $4=1)$ & 17 \\
\hline Austria & 537 & 18 & 505 & 18 & Decurnask & 136 & 1.8 & $4 \times 7$ & 18 \\
\hline Denmark & 509 & 19 & 588 & 17 & Spain & 270 & 19 & 222 & $? 0$ \\
\hline Spain & 318 & $\geq 0$ & 265 & 20 & Norway & 248 & 20 & 221 & 19 \\
\hline
\end{tabular}

Source: USPTO

\section{d. The Composition of Exported Products}

Based on the definition by OECD (1999) of knowledge-intensive industries, as shown in Table 2.17, the export of the associated products in 2000 amounted to 
$69.02 \%$ of the total expore, rising from $45.72 \%$ in 1989 . The knowledge-intensive products have become the major component of the export in Taiwan.

Table 2.17. The Structure of Manufacturung's Exports in Taiwan

\begin{tabular}{cccccccc}
\hline Year & High-tech & Med-high-tech & Med-low-tech & Low-tech & K-I & Non-Kl & Total \\
\hline 1989 & 21.55 & 24.17 & 25.73 & 28.55 & 45.72 & 54.28 & 100.00 \\
1990 & 22.86 & 25.43 & 24.49 & 27.22 & 48.29 & 51.71 & 100.00 \\
1991 & 22.82 & 26.17 & 23.85 & 27.16 & 48.99 & 51.01 & 100.00 \\
1992 & 23.70 & 27.29 & 24.04 & 24.97 & 50.99 & 49.01 & 100.00 \\
1993 & 25.43 & 28.49 & 23.13 & 22.94 & 53.93 & 46.07 & 100.00 \\
1994 & 27.26 & 28.39 & 22.01 & 22.34 & 55.65 & 44.35 & 100.00 \\
1995 & 30.59 & 29.05 & 20.41 & 19.96 & 59.64 & 40.36 & 100.00 \\
1996 & 32.22 & 28.41 & 20.16 & 19.21 & 60.63 & 39.37 & 100.00 \\
1997 & 34.37 & 27.54 & 20.51 & 17.58 & 61.91 & 38.09 & 100.00 \\
1998 & 36.78 & 26.33 & 20.29 & 16.60 & 63.11 & 36.89 & 100.00 \\
1999 & 39.42 & 26.57 & 19.21 & 14.79 & 66.00 & 34.00 & 100.00 \\
2000 & 42.69 & 26.34 & 18.21 & 12.77 & 69.02 & 30.98 & 100.00 \\
\hline
\end{tabular}

Source: OECD, STAN dacabased 2001.

ROC. Custom Import-Exporr Data, calculated by T.I.E.R.

As for the international comparison, in 2000 the proportion of exported knowledge-intensive products in the total exported in Taiwan was the highest in the world, followed by the U.S.'s $32.21 \%$, U.K.'s $29.60 \%$, South Korea's $31.49 \%$, Japan's $25.72 \%$, and Netherlands' $25.44 \%$, as shown in Table 2.18 and Figure 2.7.

Table 2.18. International Comparison of KI Manifacturing fxpurts in 1999)

\begin{tabular}{|c|c|c|c|c|c|}
\hline Country & High-tech & Med-high-tech & Med-low-tech & Low-tech & K-I Manf. \\
\hline Denmark & 14.53 & 32.59 & 19.17 & 33.71 & 47.12 \\
\hline Finland & 21.57 & 27.04 & 18.08 & 33.31 & 48.61 \\
\hline Italy & 8.45 & 42.30 & 24.63 & 24.50 & 50.75 \\
\hline Necherlands & 25.44 & 33.28 & 17.17 & 24.12 & 57.71 \\
\hline Canada & 11.54 & 47.69 & 18.03 & 22.74 & 59.23 \\
\hline Sourh Korea & 31.49 & 29.15 & 23.79 & 15.56 & 60.64 \\
\hline France & 21.17 & 43.22 & 16.05 & 19.06 & 64.38 \\
\hline Таiwan & 39.42 & 26.57 & 19.21 & {$[4.79$} & 66.00 \\
\hline U.K. & 29.60 & 41.15 & 14.97 & 13.62 & 70.74 \\
\hline Germany & 14.65 & 57.00 & 16.07 & 12.28 & 1.65 \\
\hline U.S. & 32.21 & 43.18 & 12.65 & 11.96 & 75.39 \\
\hline Japan & 25.72 & 56.95 & 14.45 & 2.89 & 82.66 \\
\hline
\end{tabular}

Source: See Table 2.17. 
Figure 2.7. The Ratio of High-Tech and K-I Exports to Manufacturing EXPORTS AMONGi Major CoUntries

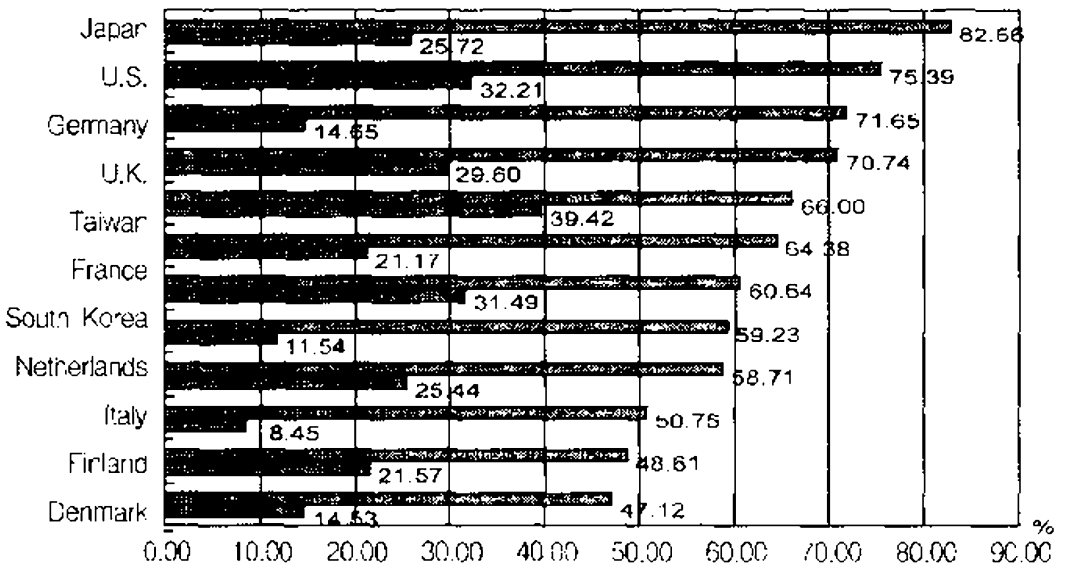

Source: Siec [ithle 2.17 .

e. The Ratio of Knowledge-intensive Industrial Value-added to GDP

When dividing knowledge-intensive industries into two groups, knowledge-intensive manufacturing industries and knowledge-intensive service industries, such developed countrics as Germany, France, the U.S., U.K., Japan, Finland, Denmark, and the like, have their knowledge-intensive service sector amounted to approximately $45 \%$ $55 \%$ of the entire industry sector. In sharp contrast, Taiwan or Sourh Korta showed the opposite, revealing the latrge room for ungrading the knowledge-intensive service sector (Sec Table 2.19).

Table 2.19. International. Comparison of Kl industries as $\%$ of DPI

\begin{tabular}{|c|c|c|c|c|c|}
\hline Country & Year & $\mathrm{Kl}$ & Manufacturing & KI Service & KI lndustries \\
\hline Ixonmark & isyy & & 8.1 .1 & 44.30 & 5.16 \\
\hline [̈irnlarad & 1999 & & 10.18 & 15.26 & $55.1 / 4$ \\
\hline italy & 1999 & & $? .35$ & 46.133 & $5+28$ \\
\hline Canada & $! 997$ & & 70.4 & 170,06 & 5.6 .10 \\
\hline Sulir!n Korca & 1999 & & 23.33 & 36.1 & 50.04 \\
\hline France & 1408 & & $? 10$ & 5.85 & $6 \geq .25$ \\
\hline Taiwas & 199 & & 13.50 & 34.11 & 保 $(0,0)$ \\
\hline U.K. & 1099 & & 7.801 & 51.56 & 54.36 \\
\hline Germany & 1098 & & 11.60 & 53.01 & $6+70$ \\
\hline U.S. & 1094 & & 8.06 & 52.35 & 60.11 \\
\hline Iapiin & 1998 & & 10.81 & 18.10 & 58.91 \\
\hline
\end{tabular}

Note: DI'l Stands for Lomestic Prokluce of Industry.

Source: ORCT), STAN Satione 200; IIER. 


\section{f. The Ratio of Knowledge Workers to the Labor Force}

Based on the definition of APEC (2000), this paper classifies legislators, business managers, and other professional personncl as the knowledge workers. As shown in Table 2.20 , in 2000 the ratio of knowledge workers to the labor force in Taiwan was $26.71 \%$, rising from $17.16 \%$ in 1987 , showing some upgrading in the knowledge intensity of the labor force.

\section{Table 2.20. KNOWLedGe WORkERS IN the LABOR ForCe in TAIWAN}

(unit: thousands, \%)

\begin{tabular}{cccccccccccc}
\hline \multicolumn{2}{c}{$\begin{array}{c}\text { Legisiators, } \\
\text { Business } \\
\text { Year }\end{array}$ Managers } \\
\end{tabular}

Saurce: TLLR.

Given the limited international data, comparison can only be made between some countries. As illustrated in Figure 2.8. Singapore's knowledge workers amounted in 1997 to $39.1 \%$ of the labor force, followed by Australia's 35.5\%. Canada's $33.3 \%$, the average of OECD countries $28 \%$, all higher than Taiwan (see Figure 2.8).

As for the employment opportunities provided by the knowledge-intensive service sector, in 1999) Taiwan's knowledge-intensive service sector amounted only to $28.43 \%$ of the tutal employment, much lower than the U.S.'s $53.77 \%$, Finland's $51.09 \%$ (in 1995), Canada's $49.14 \%$ (in 1996), and Japan's 47.16\%. Considcring the fact that more than $30 \%$ of $\mathrm{GDP}$ is attributable to the knowledge-intensive service sector in Taiwan, its employment contribution seemed relatively small (sce Figure 2.9).

The above measurement indicates the followings: (1) while Taiwan performed relatively well in the investment in education and $R \& D$, right next to that of the developed countries in general, the ICI investment on the ocher hand showed relative 
shortage; (2) similar to the above flow indicators, the selected stock indicators revealed mixed messages: while human resources in RaD showed relatively well-organized pcrformance, the national education level had obvious disadvantages conpared with the developed countries; (3) in the aspect of knowledge diffusion, our measurement indicated that ICT inftastructure and its use illustrated for the most part some distance behind the developed countries, while the composite indicator of echoological coopcration between the firms, echnology transfer berween the firms and universiries. and social value indicators in IMID 200 ] report ranked Tawan the $12^{\text {th }}$, among the leading group; (4) in the institurional set of indicators for knowledre diffusion): Taiwan seemed to be in the relatively weak position; (5) regarding the direct knowledgc output, Taiwan showed quantitatively exceptional performance both in professional publication and patents, consistent with the relative strong performance in R\&D human resources; (6) indicators for the knowledge application and econornic impact showed that Taiwan's knowledge intensive service sectur was much weaker than manufacturing scctor. Such feature suggests some development lag behind the developed countries.

To sum up, our measurement reflects the porential of Taiwan's KBE development, which nevertheless indicares considerable room for improvement. Except for ICT investment, the rest of knowledge investment indicators supported the perspcitive of Taiwan's KBE development. However, the knowledge diffusion perhaps is the weakest part for lawan's KBL development; Tawan needs much improwement in order to stay close to the developed countries. Finially, as for the knowledge output and ipplication, Taiwan's untstanding performance in rescarch publication and patents is consistent with that in R\&D human resouress, bue the obviously weak pertormance of knowledge interisive service secor might have resuled from Taiwar's relative disadvantages indicated by the measurement of the knowledge diffusion.

FIGLIRE 2.8. INTERNATTONAL COMPARISON OF KNOWI.EDGE WORKERS AS \% OF THE LABGOR FORCE IN 1997

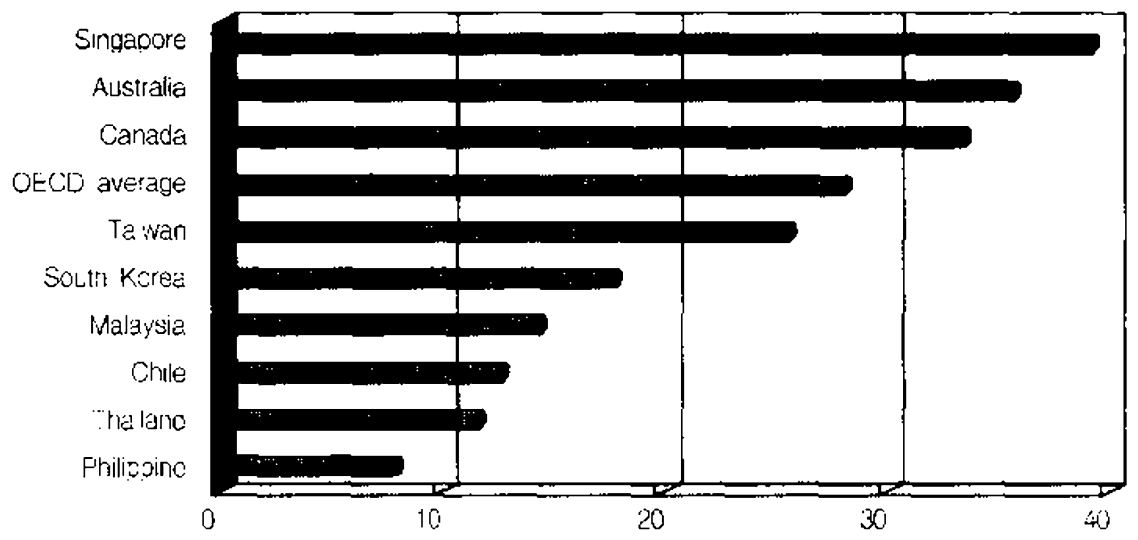

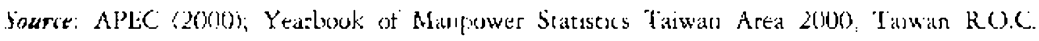




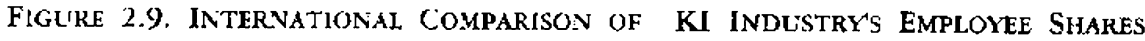

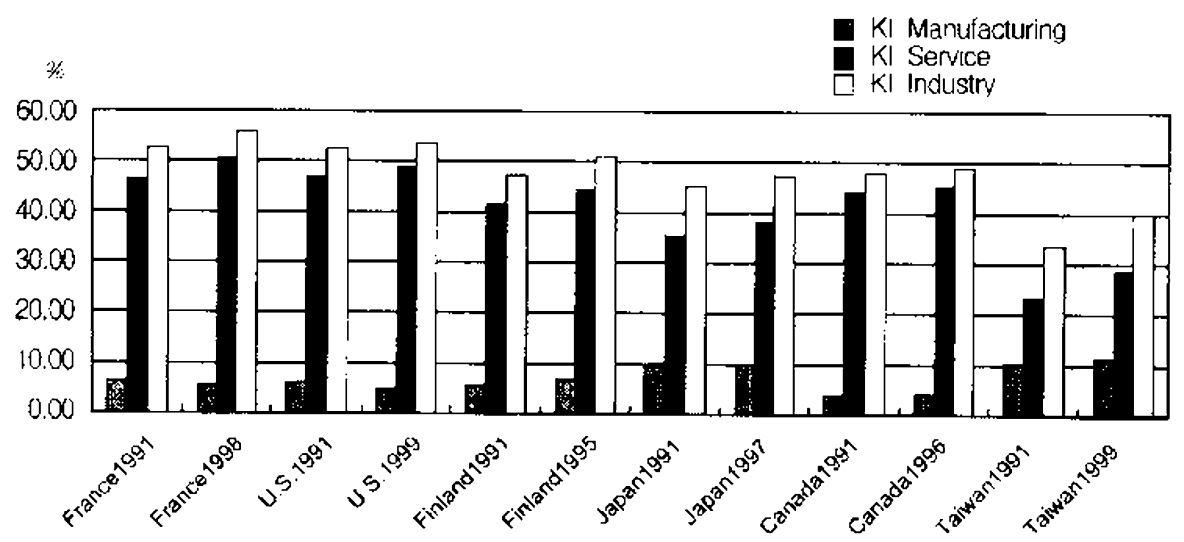

Source: OECD, STAN Database; see Figure 2.8.

\section{CONCI.USION}

One weakness in our research woukd be the failure in addressing the crucial issues such as institutional settings for promoting industrial innovation, academia- industry interaction, financial market development, human resource devclopment, innovation networks or clusters, as well as the changing international economic environment resulting from the development of globalization. It is our conviction that more research efforts should be devoted into the above areas in a more thorough and comprehensive manner.

Another shortcoming in our indicator system would be the failure of including the negative impacts resulting from the devclopment of $\mathrm{KBE}$. As widely perceived, the speedy progress of knowledge might enlarge the wealth gap hetween those who make a good use of knowledge and those who do not. Moreover, higher degree of industrial specialization but shorter life cycles of products for every country in the world may lead to more frequent excessive fluctuations owing to some unexpected changes especially in small open economics such as Taiwan. It has become more and more important to seek safeguard against the above problems as we proceed toward the $\mathrm{KBE}$. Hence, our research in this paper shall be regarded as a preliminary step toward further researches in the near future.

\section{REFERENCES}

Aghion, P. and P. Howitt. 1998. Endogenous Growth Theny: Cambridge, MA: MIT Press.

APEC. 2000. Towards Knowledge-based Economic in APEC. Report to the APEC 
Economic Committee.

Atkinson, R.D. and R.H. Court, 1998. 'lhe New Economy Index : Understanding America's Economic 'Transformation. Progressive Policy Institusc's Technology. Australia Knowledge-Based Economy Branch, 1999. Knowledge-Based Actinties:

Selected Indicators, Department of Industry, Science and Resource, Canberra.

Council of Economic Advisers, 2000. Economic Report of the President, Innited Stares Government Printing Office.

Cowan, R. and G. Paal, 2000. Innotation Policy in a Knowledg-Based Ecrnomy, a Merit Study Commissioned by the European Commission Enterprise Directoratc General.

Drucker, Peter F., 1999. Management Challenges for the 21st Century.

Ireland National Competitiveness Council, 1999. The National Comptitiveness Repunt. Leadbeater, Charles and Deroos London, 1999. "Now Measures for the New Economy." Working paper.

Massachusetrs Technology Collaborative, 1999. New Indicators for Measuring the Innovation Economy-Index of the Nassachuetts Innovation Fonomy, Massachusetts. Michael E. Porter \& Scott Stesn, 1999. The New Challenge ts American's Prosperity: Findings from the Imnowation, Council on Competitiveness Washington, D.C. OECD. 1996. The Knowledge-Based Economy. Paris.

. 1997. National Innovation Systems. Paris.

- 1999. OECD Seience, Technology and Industry Scoreboard-Benclimarking

Knowlcdge Based Economics, Paris. 1499.

. 1999. Managing Jarional Innovation System, Paris.

2000. Knowledge-based Industrics in Asia, DST!.

Robest I). Atkinson, Randolph H. Court, and Joseph M. Ward, 1999, The State

New Fonnomy Index: Benchmarking Economi Transformation in the States. (Progressive Policy Institute: Technology \& New Economic Project).

Romer, Paul M. 1986. "Increasing Returns and Long-Run Growth." Journal of Politial Economics 94: 1002-37.

U.K. Department of 'I'rade and Industry. 1999. U.K. Competitiveness Indicators 1999. U.S. Department of Commerce. 1998. The Emerging Digital Economy. 2000. Digital Economy 2000, Washington, DC: Federal Rescrve Board

Wed, B. 1999. Investing in Knowledge: On the Trade-Off between RED, ICT, Skills and Migration. Maastricht Economic Research lnstitute on Innovation and Technology (MERIT), Maastricht University.

WEF. 1999. The Global Competitivenesj Report 1999.

World Bank. 1998. World Development Report 1998-1999; Knowledge for Development, New York: Oxford University Press.

1990. "Endogenous Technological Change." Journal of Political Lounumics 98: $571-102$.

World Bank and National of Research Council. 1999. National Knouledge Assesjment Program National Knmuledge Sygtem. Washington, D.C. 